\title{
WestVirginiaUniversity
}

THE RESEARCH REPOSITORY @ WVU

Graduate Theses, Dissertations, and Problem Reports

2010

\section{Bat use of created and natural wetlands}

\author{
Marcia L. Maslonek \\ West Virginia University
}

Follow this and additional works at: https://researchrepository.wvu.edu/etd

\section{Recommended Citation}

Maslonek, Marcia L., "Bat use of created and natural wetlands" (2010). Graduate Theses, Dissertations, and Problem Reports. 2966.

https://researchrepository.wvu.edu/etd/2966

This Thesis is protected by copyright and/or related rights. It has been brought to you by the The Research Repository @ WVU with permission from the rights-holder(s). You are free to use this Thesis in any way that is permitted by the copyright and related rights legislation that applies to your use. For other uses you must obtain permission from the rights-holder(s) directly, unless additional rights are indicated by a Creative Commons license in the record and/ or on the work itself. This Thesis has been accepted for inclusion in WVU Graduate Theses, Dissertations, and Problem Reports collection by an authorized administrator of The Research Repository @ WVU. For more information, please contact researchrepository@mail.wvu.edu. 


\title{
Bat Use of Created and Natural Wetlands
}

\author{
Marcia L. Maslonek \\ Thesis submitted to the \\ Davis College of Agriculture, Natural Resources and Design \\ at West Virginia University \\ in partial fulfillment of the requirements for \\ the degree of
}

Master of Science

in

Wildlife and Fisheries Resources

\author{
W. Mark Ford, Ph.D \\ Petra Bohall Wood, Ph.D \\ John W. Edwards, Ph.D, Major Professor \\ Division of Forestry and Natural Resources
}
Morgantown, West Virginia 2010

Keywords: acoustical, Anabat, Analook, bats, echolocation, Geographic Information Systems, mitigation, monitoring, Ohio, Pennsylvania, wetland

Copyright 2010 Marcia L. Maslonek 


\title{
ABSTRACT \\ Bat Use of Created and Natural Wetlands
}

\author{
Marcia L. Maslonek
}

Compensatory wetland mitigation is a common practice to account for wetland losses due to dredging and filling under the Clean Water Act, but successful replacement of function is rarely achieved. Small, isolated wetlands also receive no federal protection, and are usually not included in accounts of losses. Although latest reports show an increase in wetlands for the first time, this is due in large part to voluntary construction of open water ponds, while the loss of freshwater emergent wetlands continues to decline. Research on the wildlife functions of wetlands has focused on plants, invertebrates, avian or amphibian species. But wetlands also are important for bat foraging habitat because most insects depend on water for some part of their life cycle. Bats could serve as a mammalian indicator of constructed wetland function due to their size, mobility, and ease of acoustic monitoring. Despite this connection, there is a lack of studies focusing on bats and wetlands in the Mid-Atlantic and Midwest, and few have occurred elsewhere.

I examined 79 constructed and natural wetlands in western Pennsylvania and eastern Ohio for the presence of bats using acoustical monitoring. The recent use of acoustical monitoring has garnered habitat level comparisons, and can be used as an index of bat activity and to determine presence and absence. I used an information theoretic approach to model the response of bats to wetland design and landscape based on the following: wetland origin, age, size, $\mathrm{pH}$, distance to highway, and areas within the surrounding landscape of forest, urban, open water, barren, wetland, and edge density.

For all species except for eastern pipistrelles (Pipistrellus subflavus), landscape characteristics influenced both presence and relative activity of observed bat species. The Combo model incorporated wetland size as well as landscape parameters, and received support for most species, with differences among species based on wing morphology and habitats. Within supported models, surrounding wetlands in the landscape had the greatest influence on most bat species. Big brown bats (Eptesicus fuscus) were influenced by barren and open areas, while eastern red bats (Lasiuris borealis) were influenced by agriculture. Wetlands created in a landscape with an overall lack of wetlands and less edge may be particularly important for all species of bats, regardless of wing morphology. My results also showed that wetlands of all sizes, even small ones not afforded federal protection, can be vital foraging areas for bat species. The wetland origin and abiotic characteristics received no support, suggesting that placement within the landscape may be the most important consideration for bats. The origin of the wetland only influenced activity for eastern pipistrelles, which may be due to the closed canopy associated with natural wetlands. With the latest research in developing indices of biotic integrity for various groups of wildlife such as birds, amphibians, and plants, a mammalian indicator group should also be considered. Because of the association of bats with wetlands, relative ease of acoustical monitoring, and importance of wetlands to mammals in general, bats may be good candidates to develop as a mammalian indicator for wetland function. 


\section{ACKNOWLEDGMENTS}

I would like to thank Dr. John Edwards for the opportunity to further my knowledge of wildlife management and restoration, and especially for being supportive of a non-traditional student and the challenges that accompanied my situation. I also thank Dr. W. Mark Ford for his always-patient answers to my countless questions, and for his assistance in chasing the elusive hoary bat. I also thank Dr. Petra Bohall Wood for her support, and for her commitment to a high standard of research.

Dr. Mike Strager of the Division of Forestry and Natural Resources, WVU, provided patient assistance with the spatial analysis and Geographic Information Systems. Thanks to Josh Johnson of the University of Maryland for reviewing bat calls and providing guidance on analyses and acoustical monitoring. Dr. George Seidel of WVU also provided helpful suggestions and guidance regarding statistical analysis.

I also thank the numerous private landowners who graciously allowed a stranger to access their land in the middle of the night. I enjoyed meeting everyone, and am grateful for the chance to illuminate the world of bats. I also thank the Pennsylvania Department of Transportation, Annette Paluh and Greg Holesh at the Pennsylvania Department of Environmental Protection, Pennsylvania Game Commission, Muskingum Watershed Conservancy District, BFI Imperial Landfill, CONSOL, Mosquito Lake Wildlife Area, and the other organizations who granted permission to access their properties. Lastly, I must thank my family for their patience and support. 


\section{TABLE OF CONTENTS}

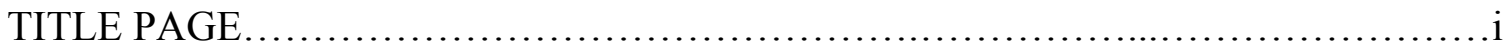

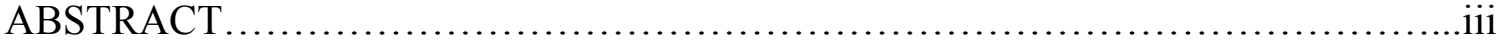

ACKNOWLEDGMENTS..........................................................

TABLE OF CONTENTS ...........................................................

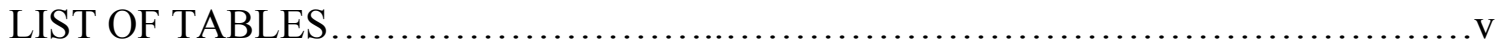

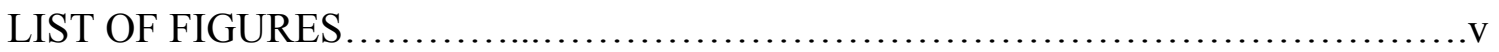

LIST OF APPENDICES ................................................................

CHAPTER 1: INTRODUCTION.......................................................................................1

Introduction, Research Justification, and Objectives...........................1

\section{CHAPTER 2: LITERATURE REVIEW OF BAT \\ ECOLOGY AND WETLANDS..........................................................}

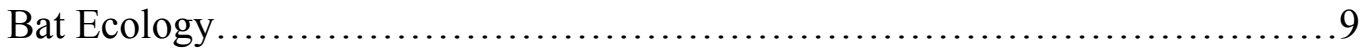

Foraging and Use of Wetlands...............................................

Wetland Policy and Mitigation.......................................... 15

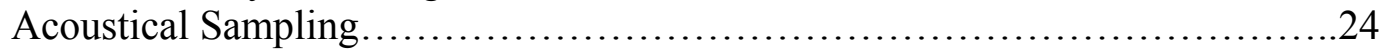

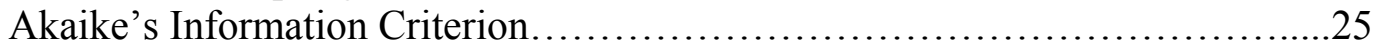

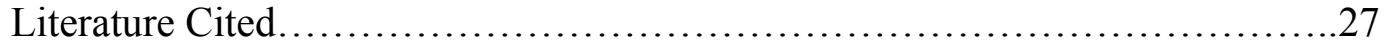

CHAPTER 3: BAT USE OF CREATED AND NATURAL WETLANDS............45

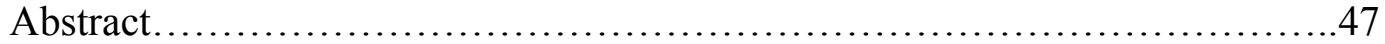

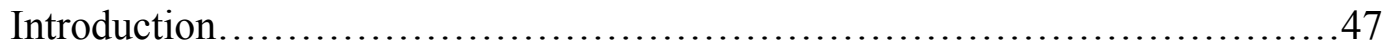

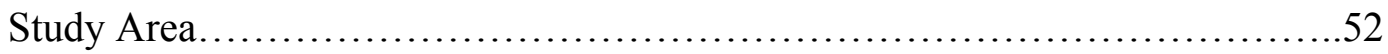

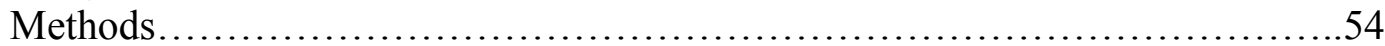

Site Selection....................................................... 54

Landscape Analysis................................................. 55

Acoustical Sampling..............................................5

Statistical Analysis..................................................59

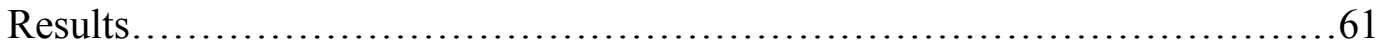

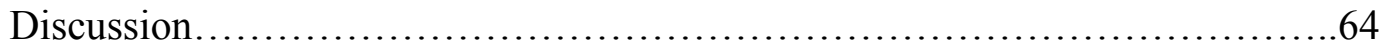

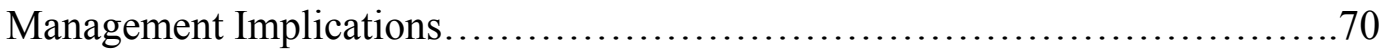

Literature Cited......................................................... 71 


\section{LIST OF TABLES}

Table 2-1. Characteristics of sampled wetlands $(n=79)$ in western Pennsylvania and eastern Ohio, 2004-2005.

Table 2-2. Age categories of sampled wetlands $(n=79)$ in western Pennsylvania and eastern Ohio, 2004-2005.

Table 2-3. Biotic and abiotic parameters included in negative binomial and logistic regression models explaining wetland and landscape relationship of bat presence and relative abundance in sampled wetlands in western Pennsylvania and eastern Ohio, 2004-2005

Table 2-4. Model set explaining wetland and landscape relationship of bat presence and relative abundance in sampled wetlands in western Pennsylvania and eastern Ohio, 2004-2005.

Table 2-5. Logistic regression analysis and model selection using Akaike Information Criteria (AICc) difference with correction for small sample sizes $(\Delta$ AICc ) and model weight (wAICc) for wetland characteristics and presence/absence of each bat species at each wetland $(n=79)$ in western Pennsylvania and eastern Ohio, June-August, 2004-2005.

Table 2-6. Negative binomial regression analysis and model selection using Akaike Information Criteria (AICc) difference with correction for small sample sizes ( $\triangle \mathrm{AICc}$ ) and model weight (wAICc) for wetland characteristics and species richness and foraging activity recorded and number of recorded bats at each wetland $(n=79)$ in western Pennsylvania and eastern Ohio, June-August, 2004-2005.

Table 2-7. Variables included in best approximating candidate models selected using Akaike Information Criteria $\left(\mathrm{AIC}_{c}\right)$ within logistic regression analysis predicting bat presence at wetlands.

Table 2-8. Variables included in best approximating candidate models selected using Akaike Information Criteria $\left(\mathrm{AIC}_{c}\right)$ within multiple regression analysis predicting bat

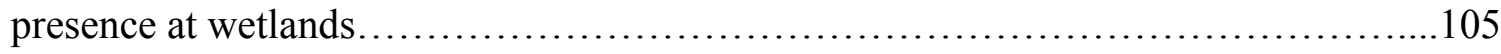

\section{LIST OF FIGURES}

Figure 1-2. Sampled wetland locations $(n=79)$ in western Pennsylvania and eastern

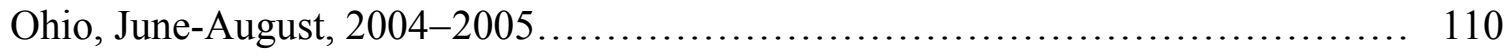




\section{LIST OF APPENDICES}

$\underline{\text { Page }}$

Appendix A. Difference in bat species richness as recorded for each wetland $(n=79)$ by year in western Pennsylvania and eastern Ohio, June-August, 2004-2005 ................. 111 
Chapter 1

Introduction, Research Justification, and Objectives 


\section{INTRODUCTION, RESEARCH JUSTIFICATION, AND OBJECTIVES}

Throughout North America and elsewhere, the presence of bats often is associated with riparian and wetland habitats (Zimmerman 2000, Siedman 2001, Russo and Jones 2003, Menzel et al. 2005, Ford et al. 2006). In the mid-Atlantic region, all bat species are insectivorous and all extant species utilize wetlands, one of the world's most productive environments (Ramsar Convention Secretariat 2007), as foraging habitat (Francl et al. 2004a). Wetlands are important for bats because of availability of water and high insect densities (Vauhgn et al. 1997, Russo and Jones 2003, Flaquer et al. 2009), with many insects depending on water for some part of their life cycle (Gordon and Serfass 1989, Imes 1992). Despite this, the importance of wetlands to bats has been neglected relative to other taxa such as waterbirds (Flaquer et al. 2009).

Insectivorous bats have been shown to selectively forage over open water (Brigham and Fenton 1991, Krusic et al. 1996, Walsh and Harris 1996, Grindal and Brigham 1999, Francl et al. 2004b). But there are limited studies on wetlands as bat foraging habitat (Arnett 2003, Miller et al. 2003), and even fewer examining restored or created wetlands (Menzel et al. 2005a). Studies of bat habitat selection/use demonstrate relatively higher activity over wetlands than forest interior (Zimmerman and Glanz 2000, Francl et al. 2004b, Brooks and Ford 2005, Francl 2008). In the southeastern United States, Menzel et al. (2005) examined bat activity over pre- and post-restored Carolina bays, as well as in forest interior sites, and found activity highest over restored Carolina bays after just one year. Another study focused on woodland seasonal pools in the northern Great Lakes region, and found that pools of all sizes were important for bat foraging (Francl 2008). A study in Kentucky examined constructed woodland ponds, and found multi-season use by bats (Huie 2002). In Arkansas, Wilhide et al. (1998) found 
that even water-filled ruts and small ponds provided foraging habitat for bats. Studies of bat habitat associations reveal that proximity to water features is important for bat activity in the mid-Atlantic region (Fenton and Barclay 1990, Owen et al. 2003, Brooks and Ford 2005, Schirmacher et al. 2007), Southeast (Menzel et al. 2005, Ford et al. 2006), Southwest (Rogers et al. 2006), Mexico (MacSwiney et al. 2009), and Europe (Rydell et al. 1994, Russo and Jones 2003, Downs and Racey 2006, Flaquer et al. 2009).

In the United States, $47 \%$ of wetlands have been lost since the 1780s; Ohio alone has lost over 90\% of its wetlands (Dahl 1990). Between 1998 and 2004, wetland gains exceeded losses for the first time in history, with a net gain of 77,630 ha (191,750 acres) (Dahl 2006). However, freshwater ponds accounted for the net gain with an increase of 281,500 ha (700,000 acres), whereas freshwater emergent marshes decreased by 57,720 ha (142,570 acres) (CEQ 2005, Dahl 2006). The functions that emergent wetlands provide to the environment are then lost, including water quality improvement, groundwater recharge, and habitat for wildlife (Mitsch and Gosselink 2000). Although there is no overarching federal wetland policy, limited protection is afforded by 1977 amendments to the Clean Water Act (Mitsch and Gosselink 2000). Originally, Section 404 did not reference wetlands, only "navigable waters," which limited its application. Subsequent court cases led to amendments to clarify wetlands as a resource to be protected (Mitsch and Gosselink 2000). The U.S. Army Corps of Engineers and the Environmental Protection Agency are responsible for Section 404 permits that regulate impacts to wetlands associated only with navigable waters (Bedford and Godwin 2003). Any dredging or filling of wetlands requires a permit, although exceptions are granted. If wetland loss or damage is unavoidable, it must be mitigated through replacement or 
enhancement. Wetlands not directly connected to navigable waters are considered isolated for regulatory purposes and excluded from federal jurisdiction. Protection of isolated wetlands therefore occurs only at the state level, and varies among states (Osmond et al. 1995).

The type and size of a wetland are primary criterion for determination of the mitigation extent for both state and federal wetland regulations (Snodgrass et al. 2000). The U.S. Army Corps of Engineers regulates navigable waters and usually allows wetlands $<4.0$ ha ( 9.9 acres) to be destroyed under a blanket permit (National Wetlands Policy Forum 1988). Between 1998 and 2004, 85\% of freshwater wetland losses were less than 2.0 ha (5.0 acres) in size, with half of those wetlands less than 0.4 ha ( 1.0 acre) (Dahl 2006). Small wetlands may also comprise the majority of wetlands in certain areas; in Maine, for instance, over $62 \%$ of wetlands are $<4.0$ ha (Gibbs 1993). Rationale for this policy is based on the presumption that small wetlands support few species and that these species are also found in larger wetlands. Several studies of amphibians suggest that small wetlands may be as important as larger ones in supporting biodiversity (Semlitsch and Bodie 1998, Snodgrass et al. 2000, Francl et al. 2004); Snodgrass et al. (2000) reported no difference in species richness among wetlands of various sizes. Moreover, the loss of relatively small $(<1.2 \mathrm{ha}, 3.0$ acres) wetlands could increase dispersal distances and possibly isolate source populations of amphibians (Semlitsch and Bodie 1998). Small, isolated wetlands in West Virginia were similar in characteristics to larger ones and harbored wetland species distributed patchily across the landscape (Francl et al. 2004). Metapopulations depend upon a mosaic of wetlands, and therefore wetlands as small as 0.4 ha in size should receive protection (Gibbs 2000). 
In addition to replacing the impacted wetland acreage, functions of lost or degraded wetlands also must be mitigated. A successful mitigation may be defined as one that "provides habitat that is functionally equivalent to the one that was lost" (Zedler 1996). Determining this functionality, and how to achieve it, has been the subject of debate within the wetland science community (National Research Council 1992). For a created wetland, hydrophytic vegetation is one simple measure of structure often utilized and related to function. Animal communities and species diversity are common ecosystem functions that can be used to characterize constructed wetlands and design performance standards (Brinson et al. 1994, Brinson and Reinhardt 1996). But such functions are rarely monitored because they are more difficult to measure than percent surface water or plant cover (Mitsch and Wilson 1996, NRC 2001). Studies have focused on wildlife value as a wetland function by examining avian (Hickman 1994) or amphibian richness (Funk and Dunlap 1999, Monello and Wright 1999, Lehtinen 2001). Despite the value of wetlands to bats, no studies have examined bat use of created wetlands in the Mid-Atlantic or Midwest regions, and only one occurred in the Southeast (Menzel et al. 2005). Bats may serve as an important mammalian indicator species in wetland functionality assessment as they are closely associated with wetlands. A mammalian indicator is warranted because a large percentage of mammals are believed to benefit from wetland habitats (Gordon and Serfass 1989). Bats may be especially well suited to this role because of their dependence on wetlands for foraging, ease in monitoring with the advent of acoustical technology, and ubiquitous distribution across landscape types ranging from urban to forest, unlike many other wetland dependent species. 
My study examined wetland characteristics (e.g. size, age, origin [natural or constructed], $\mathrm{pH}$, and surrounding landscape features) associated with use and presence/absence of bats in the Upper Ohio Valley region. I hypothesized that characteristics such as size and origin of wetlands would not negatively impact bat communities, while $\mathrm{pH}$ and surrounding land use may deter bat use. Because bats are highly mobile, and depend on wetlands for prey and access to water, I hypothesized that they are adaptable to different sized wetlands, and not affected by the origin because vegetation structure within the wetland is not important in the same manner as for nesting birds (Snell-Rood and Cristoll 2003). Insects are quick to appear in constructed wetlands, and many species that comprise bat diets, such as dipterans, are tolerant of a wide variety of $\mathrm{pH}$ conditions (Harvey et al. 1999).

Bats are likely to be influenced by the landscape conditions within their home range, such as forest, urban areas, and agriculture which impact breeding habitat, foraging, and travel routes. Differences in habitat will impact species based on wing morphology. Hoary and big brown bats are less maneuverable due to high wing loadings and therefore forage in open, clutterless areas (Owen et al. 2004, Menzel et al. 2005). Little brown bats, pipistrelles, and eastern red bats are clutter-adapted due to low wing loadings and can utilize closed-canopy habitats (Menzel et al. 2003, 2005, Ford et al. 2005). Less maneuverable species therefore may be impacted positively by open landscapes, larger wetlands, and increased edge density.

Specific objectives and hypotheses of my project were to:

(1) Compare species richness and relative activity of bats using constructed and natural wetlands. 
$\mathrm{H}_{1}$ : Species richness will be greater in larger created wetlands.

$\mathrm{H}_{2}$ : Richness and relative activity of bats will be greater at wetlands with higher edge density and forest in the surrounding landscape.

$\mathrm{H}_{3}$ : Richness and relative activity of bats will decrease as distance from wetland to road and urban area increases.

(2) Determine influence of wetland characteristics on bat presence/absence and use.

$\mathrm{H}_{1}$ : Landscape characteristics will influence bat presence more than physical attributes alone such as origin, age, or size.

$\mathrm{H}_{2}$ : Species that prefer less cluttered environments will be positively influenced by higher edge density, open landscapes, and larger sized wetlands.

(3) Develop wetland design recommendations for enhancing bat habitat in wetland construction and mitigation projects. 
Chapter 2

Literature Review of Bat Ecology and Wetlands 


\section{Bat Ecology}

There are 45 bat species in the United States, eleven of which are found in northeastern Ohio and southwestern Pennsylvania (Harvey et al. 1999). Bats are in the order Chiroptera, and the aforementioned 11 species are in suborder Microchiroptera and family Vespertilionidae. About $70 \%$ of the world's bat species, and all of the species within the study area, are insectivores. Life span among bat species varies but can be more than 20 years (Harvey et al. 1999). All threatened or endangered bat species in North America are cave dwelling for some portion of the year (McCracken 1989, Pierson 1999).

Myotid species within Upper Ohio Valley region of western Pennsylvania and eastern Ohio include the little brown bat (Myotis lucifugus), northern myotis ( $M$. septentrionalis), Indiana bat (M. sodalis), and eastern small-footed bat (M. leibii). The big brown bat (Eptesicus fuscus) and eastern pipistrelle (Pipistrellus subflavus) are also common. Species of tree bats include red bat (Lasiurus borealis), hoary bat (L. cinereus), evening bat (Nycticeius humeralis), and silver-haired bat (Lasionycteris noctivagens) (Harvey et al. 1999). The Seminole bat (Lasiurus seminolus) is not considered a regular resident, but has been recorded several times in Pennsylvania (Fergus 2002). The Indiana bat is the only federally and state endangered species in the region. The eastern smallfooted bat is of special concern (Harvey 1997).

During spring and early summer, bat species give birth and raise young. For most species, such as the Myotids, roosts may consist of colonial roosts of females and young, or bachelor roosts for males, within snags, tree cavities, or artificial structures such as buildings. Tree bats, such as the red bat and hoary bat, are solitary and primarily roost 
under the bark of trees or within foliage (Shump and Shump 1982). Bats spend most of the day inside these roosts, so choice may be an important influence on survival and fitness (Vonhof and Barclay 1996). Mature, upland forests are important sites for day roosts, especially when near riparian corridors used for foraging (Waldien et al. 2000, Cryan et al. 2001, Baker and Lacki 2006). The use of night roosts is a rarely examined aspect of bat ecology, but night roosts may be the same structure as used during the day, and may be used by multiple species (Barbour and Davis 1969, Agosta et al. 2005). Night roosts are often in close proximity to foraging areas (Agosta et al. 2002), and provide critical places to rest between feeding, and for protection from predators and weather (Wilkinson 2002).

During fall, bats exhibit a behavior called swarming, where large numbers of bats congregate within and around cave entrances, even though many do not roost within them during the day (Fenton 1969). Copulation occurs during swarming, highlighting the importance of such areas for reproduction (Hall 1962, Cope and Humphrey 1977). Swarming is not completely understood, but may also aid in hibernacula selection. During winter, most bats migrate to mines, caves, and anthropogenic structures for hibernation, usually traveling less than 482 kilometers (300 miles) (Tuttle 1997). Hibernation sites are chosen based on a suite of conditions specific to each species, such as temperature and humidity, and are sensitive to anthropogenic disturbances (Barbour and Davis 1969, McCracken 1989).

Tree bats also swarm and may migrate hundreds of kilometers each season from breeding to wintering grounds, where they roost in leaf clusters and branches (Barbour and Davis 1969, O'Shea et al. 2003). Far less is known about the migration patterns of 
tree bats (Menzel et al. 2003). Because tree bats have a low reproductive capacity and long life span of 30 years, their populations may have difficulty recovering from habitat loss, catastrophes, or other impacts due to slower rate of recruitment (Findley 1993).

\section{Bat Foraging and Use of Wetlands}

Three primary factors influence foraging in bats: wing morphology, prey abundance, and echolocation call structure (Barclay 1985, Aldridge and Rautenach 1987, Menzel et al. 2005). Species with high wing loadings, such as hoary and big brown bats, are less maneuverable, and therefore forage in open, clutterless areas (Owen et al. 2004, Menzel et al. 2005). Species with low wing loadings, such as little brown bats, pipistrelles, and eastern red bats, are clutter-adapted and can utilize closed-canopy habitats (Menzel et al. 2003, 2005, Ford et al. 2005).

Despite wing morphology, most bat species are known to roost in forests and travel to open sites to forage (Grindal and Brigham 1999, Francl et al. 2004b). Clutteradapted species such as the little brown bat and pipistrelle often use large water bodies and open spaces, suggesting foraging habitat selection may be influenced more by prey abundance or availability and foraging ease than wing morphology alone (Ford et al. 2005). Other studies have found open areas in heavily forested habitats are important foraging habitat for big brown bats, little brown bats, hoary bats, and pipistrelles, regardless of wing morphology (Francl et al. 2004b, Owen et al. 2004).

The low structure and high insect abundance that edge creates makes this habitat important for bats (Crampton and Barclay 1998, Hogberg et al. 2002, Menzel et al. 2002, Schirmacher et al. 2007). Red bats are often detected feeding and traveling along forest edge (Kunz 1973, Hart et al. 1993, Harvey et al. 1999), especially when combined with 
water sources such as open and wooded streams, or ponds and lakes (Davis and Mumford 1962, Schirmacher et al. 2007). But they also demonstrate wide habitat associations due to body size and diet (Carter et al. 2004, Menzel et al. 2005, Schmiracher et al. 2007). Within the central Appalachians of West Virginia, the low structural complexity and high insect abundance of edge habitat is important for bats (Crampton and Barclay 1998, Hogberg et al. 2002, Menzel et al. 2002). The most meaningful associations include open or closed canopy and proximity to water (Schirmacher et al. 2007).

Insectivorous bats often selectively forage over open water in temperate regions (Brigham and Fenton 1991, Krusic et al. 1996, Walsh and Harris 1996, Grindal and Brigham 1999, Francl et al. 2004b). Pipistrelles and little brown bats use a relatively small foraging area encompassing waterways and edge habitat (Harvey et al. 1999). In the northern part of its range, the Indiana bat forages primarily in wetlands (Kurta and Whitaker 1998), along edges and in riparian areas (Clark et al. 1987, Humphrey et al. 1977, Brack 1983, Menzel et al. 2001). Red bats are often detected feeding and traveling along forest edge, especially when combined with water sources such as open and wooded streams, or ponds and lakes (Kunz 1973, Hart et al. 1993). Hoary bats are known to frequent habitats with expanses of open water and travel above the canopy (Hart et al. 1993). Bat foraging and prey abundance may be higher over calm, quiet water, such as wetlands, as compared to turbulent waters that may interfere with echolocation (Von Frenckell and Barclay 1987, Zimmerman and Glanz 2000). A study of bat activity in Massachusetts forests also found high bat activity over still-water habitats, with greatest activity over large ponds (Brooks and Ford 2005). Overall, bat 
foraging habitat is optimized with moderate clutter, some structure, and nearby water (Menzel et al. 2005, Schirmacher et al. 2007).

In Maine, a study of habitat use at various scales, with an emphasis on wetlands, found that bat activity was concentrated over ponds, gravel roads, and lakes (Zimmerman and Glanz 2000). Although wetlands were expected to be productive, bat activity was low, but low temperatures may have reduced prey base and activity (LeSage and Harrison 1980). Elevated bat activity over roads and edges may result from commuting rather than foraging by bats (Limpens et al. 1989), which also occurs over streams (Krusic et al. 1996). Zimmerman and Glanz (2000) suggest that managers consider both foraging and roosting habitat in developing management plans, including factors like insect availability and water retention of small ponds and lakes.

One study examined bat activity over Carolina bays pre- and post-restoration with reference wetlands in the southeast (Menzel et al. 2005). Carolina bays are important for wildlife because of their ephemeral nature and isolation from other sources of water. Restoration of bays created an open wetland area in a dry landscape and improved foraging for bats; bat activity increased almost immediately upon restoration. Bat activity was also greater over bays as compared to interior forest (Menzel 1998, Menzel et al. 2005). Because dense forests are relatively more difficult for bats to navigate (Broders et al. 2003), interior forest is generally thought to be poor for foraging (Owen et al. 2004).

Several studies examined bat use of seasonal woodland pools. Francl et al. (2008) studied bat activity at seasonal ponds in the northern Great Lakes, and found that relative bat activity was significantly influenced by pool size, with more bats at small or large 
sized pools. Little brown bats were the most common species and found across pools of all sizes, while hoary, red, and big brown bats were more common at larger pools. The smaller bats are capable of utilizing all sized wetlands, while the larger bats are limited to the more open pools. As open water declined, so did bat activity. Likewise, bat activity over pools in forests of Massachusetts also followed the pattern of high activity over all pools, with greatest activity and bat diversity over large ponds (Brooks and Ford 2005).

Several studies from outside the United States have examined wetland use of bats. In Spain, Flaquer et al. (2009) radiotagged Nathusius' pipistrelle (Pipistrellus nathusii) to assess their foraging habitat selection of wetlands, and found wetlands were key for foraging. Flooded rice fields, considered important for waterbirds (Fasola and Ruiz 1996), were avoided by pipistrelles. This raises a caution for automatically extending conservation measures for one suite of species to others (Russo et al. 2005, Flaquer et al. 2009). In Mexico, MacSwiney et al. (2009) found that insectivorous bat activity and foraging was greater in habitats with cenotes, water-filled sinkholes, than those without, and urged protection of this habitat and surrounding landscape.

Diets of insectivorous bats in the United States include Coleopterans, Lepidopterans, Dipterans, and Homeopterans, although variation among species occurs. Little brown bats feed on chironomids (Diptera), and caddisflies (Bellwood and Fenton 1976, Agosta and Morton 2003). Indiana bats forage in specific habitats but feed opportunistically on available insects (Bellwood and Fenton 1976, Fenton and Morris 1976, Whitaker 1995, Menzel et al. 2001). Northern myotis are also considered an opportunistic forager (Kunz 1973); however, others consider the species a gleaner, capturing Arachnids in particular (Whitaker 2004). Big brown bats feed on scarab 
beetles (Hamilton and Barclay 1998, Whitaker 1995) and later in summer, green stink bugs (Acrosternum hilare) (Agosto and Morton 2003). Lasiurine bats primarily feed upon moths (Lepidoptera) and beetles (Coleoptera) (van Zyll de Jong 1985), but also on flies and mosquitoes (Diptera) and other insects (Harvey et al. 1999). The larvae of many Dipterans, such as chironomids and mosquitoes require water, as well as other insect larvae and adults such as caddisflies (Imes 1992). Because prey abundance is a critical factor in determining foraging patterns of bats in temperate regions (Barclay 1985, Gordon and Serfass 1989, Jung et al. 1999, Menzel et al. 2005), and most insects depend on water for some part of their life cycle (Imes 1992), wetlands provide an important foraging habitat for many bat species.

\section{Wetland Policy and Mitigation}

In the contiguous United States, $47 \%$ of wetlands have been lost since the 1780 s, with highest losses in intensive agriculture states such as those in the mid-west; Ohio alone has lost over 90\% of its wetlands (Dahl 1990). Between 1998 and 2004, wetland gains exceeded losses for the first time in history, with a net gain of 77,630 ha $(191,750$ acres) (Dahl 2006). However, freshwater ponds accounted for the net gain with an increase of 281,500 ha (700,000 acres), while freshwater emergent marshes decreased by 57,720 ha (142,570 acres) (CEQ 2005, Dahl 2006). The functions that wetlands provide to the environment are then lost, including water quality improvement, groundwater recharge, and habitat for wildlife (Mitsch and Gosselink 2000).

Some wetlands receive federal protection under the Clean Water Act (CWA) of 1972 and the 1977 amendments that aim "to restore and maintain the chemical, physical, and biological integrity of the Nation's waters" (Federal Water Pollution Control Act, 
Public Law $92-500$ ). Because wetlands can improve water quality, reduce sedimentation, and aid in nutrient cycling, wetlands are included in the definition of "waters" in order to achieve the goals of the CWA (United States v. Riverside Bayview Homes, Inc., 474 U.S. 121 (1985)).

The CWA places responsibility upon the Army Corps of Engineers and the Environmental Protection Agency to regulate wetland impacts by enforcing Section 404 permits. Permits are required to fill, drain, or degrade a wetland because of the impact on water quality. Agencies delineate wetlands following a three-part examination of hydrology, soil, and vegetation (NRC 1995). Jurisdictional wetlands must periodically support hydrophytic vegetation, consist of predominantly hydric soil, and be saturated with water or covered by shallow water at some time during the growing season (Cowardin et al. 1979, Dahl 2006).

Interpretation of a protected wetland under the CWA has changed since its inception. In 2001, the U.S. Supreme Court issued a decision that altered Section 404 permitting to no longer protect isolated wetlands (Bedford and Godwin 2003), leaving states responsible for determining regulatory requirements of these wetlands (Osmond et al. 1995). Isolated wetlands are defined as wetlands not connected to navigable waters. The Solid Waste Agency of Northern Cook County v. United States Army Corps of Engineers (531 U.S. 159, 2001) is referred to as the SWANCC decision. This case involved the "Migratory Bird Rule" adopted in 1986 that stated waters used by migratory birds could qualify wetlands for protection due to the commerce clause within the Army Corps' definition of "waters of the United States" (Kusler 2004). The decision removed 
Clean Water Act jurisdiction over isolated wetlands because they are not adjacent to navigable waters or tributaries.

The SWANCC decision also weakened the State 401 permits required for federally permitted activities (Porej 2003, Kusler 2004, Kettlewell 2005). Efforts have been made by states to fill in the gaps as a result of the decision (Want 1994). According to Kusler (2004), 18 states have legal protections for isolated wetlands, including both Pennsylvania and Ohio. Ohio has adopted legislation and extended water quality programs to include isolated and other wetlands. Pennsylvania has an existing comprehensive wetland legislation that fulfills a similar role and protects nearly all wetlands.

In 2006, the U.S. Supreme Court ruled that the ACOE exceeded its authority in denying two developers permits on wetlands linked to navigable waters by drainage ditches (Rapanos et al. v. United States 2006, Carabell v. U.S. Army Corps of Engineers, 2006). This further complicated the interpretation of "significant nexus." The EPA and Department of Army issued guidance regarding CWA jurisdiction in 2007, but received over 65,000 public comments. Revised guidance was then released in December 2008 to clarify the definitions of "traditional navigable waters," adjacent wetlands, and the concept of "relevant reach." A wetland is considered adjacent if it has a continuous surface connection to jurisdictional waters, directly abuts, is separated by a berm, or is in reasonably close proximity to navigable waters. A significant nexus is determined by flow and function of the tributary and adjacent wetland to assess "if they significantly affect chemical, physical, and biological integrity" of the waters (USACE/EPA 2008a). Waters not protected include those that do not flow at least three months, swales or small 
washes, and ditches. A hydrologic connection alone is not sufficient. This is of particular concern to arid-region states (USACE/EPAb 2008).

The Conservation Foundation introduced the "no net loss" goal in 1988 before it was adopted by the national committee as policy in 1990, and announced as a Presidential Goal in 2004 (CEQ 2006). The committee defined a wetland as "an ecosystem that depends on constant or recurrent, shallow inundation or saturation at or near the surface of the substrate." The national policy is instrumental in requiring that wetland loss be avoided or minimized before compensatory mitigation is undertaken (Mitsch and Gosselink 2000). Mitigation requires that wetlands lost to development must be compensated for by constructing or restoring wetlands, or that existing wetlands elsewhere will be protected. Wetland restoration is the process of returning a disturbed or altered wetland to its previously existing condition; wetland creation is the man-made process of converting upland into wetland (NRC 1992). The mitigation is designed to offset the loss of specific wetland functions and associated values, including habitat, within the watershed (NRC 2001). Compensatory mitigation wetlands are a common form of created wetlands arising from this policy.

If a wetland meets the initial definition for protection under a 404 permit, the next criterion is to determine if compensatory mitigation is required is the size of the impacted wetland (Snodgrass et al. 2000). The Army Corps of Engineers considers wetlands over 0.13 ha as jurisdictional, with sites that are less than 4.1 ha ( $<10$ acres) usually allowed to be developed (NWP 26). This leaves small isolated wetlands, perhaps "one of the most important and threatened ecosystems in the United States," without protection (Osmond et al 1995). Dahl (2006) reports that, between 1998 and 2004, 85\% of freshwater wetland 
losses were less than 2.0 ha (5.0 acres) in size, with $52 \%$ of those wetlands less than 0.4 ha (1.0 acre). Cumulative wetland losses across the United States are likely higher than reported due to the loss of small isolated wetlands that are not accounted for (Gladwin and Roelle 1992, Race and Fonseca 1996).

\section{Wetland Creation and Restoration}

The process of wetland creation or restoration involves numerous stages. The first stage is determining the watershed location (National Research Council 2001) based on defined objectives. The no-net-loss policy promotes in-kind, on-site mitigation, where wetlands of one kind, such as emergent wetlands, are replaced with the same kind adjacent to the discharge site (NRC 2001). Despite this policy, most compensatory wetlands are designed as ponds with a fringe of emergent vegetation (Kentula et al. 1993, Dahl 2000). Such wetlands are easier to construct (Cole and Shafer 2002, Porej 2003), most likely to meet ACOE requirements (USACE 1987), and the difference does not have to be reported (Kettlewell 2008). Proximity to the development that precipitated the need for mitigation often causes changes in hydrology, altered landscapes, and other issues that jeopardize the likelihood of success for in-kind replacement (Erwin 1991, Kentula et al. 2004). Agencies can decide if a mitigation occurs "in close proximity" and "to the extent possible" in the same watershed, if the environmental gain is deemed greater (USACE/EPA 1990).

The second stage is a site design plan to secure target functions. The NRC committee (2001) suggests that wetland design and local setting within the landscape determine the resulting ecological functions of the created wetland. Plans are based on the wetland's structure and location to achieve a desired function, or to replace the same 
kind of wetland. Compliance is ascertained by a variety of approaches, from implementing an approved plan, called a design standard, to achieving a measure of function, referred to as a performance standard (NRC 2001). Common ecosystem functions that can be used to characterize wetlands and design performance standards include: hydrologic, biogeochemical, plant community maintenance, animal community maintenance, water balance, and species diversity (Brinson et al. 1994, Brinson and Reinhardt 1996).

Hydrology is perhaps the most critical dimension to the wetland design, as well as soils and elevation (Lowry 1990, Mitsch and Gosselink 2000). Although wetland science is well established, created wetlands often fail due to unsuitable hydrology (Bedford 1996). On-site mitigation often occurs in urban areas, contributing to altered and problematic hydrology (Erwin 1991). A hydrological study, or water budget, is conducted to ensure that ground water and/or surface water is sufficient to maintain proper wetland conditions (Lowry 1990). Frequent, natural inundation is important for success (Willard et al. 1989), although some engineers use artificial water level controls (Lowry 1990). The wetland should require little to no long-term maintenance, and be self-sustaining (Mitsch and Gosselink 2000).

The third stage is site acquisition, construction, and inspection. Excavation considerations include determining the subgrade based on the final thickness of soils to be deposited, ability to grade the soils to specified elevations, erosion control, and logistics of soil deposition, especially if water level controls may be needed (Lowry 1990). Elevations are crucial in order to support the desired vegetation and provide habitat, and can be determined through well studies and the water budget (Heaven et al. 
1993). Obligate, emergent wetland vegetation will thrive in the lowest elevations, while shallower areas will be suitable for facultative wetland species (Reed 1998, Heaven et al. 1993). Final contouring should be gentle, ideally less than 3\% (Lowry 1990).

Soils are important for wetland design. Characteristics should be assessed for permeability and texture, as well as chemistry that may influence the water quality or productivity of the future wetland such as toxins (Willard et al. 1989, Mitsch and Gosselink 2000). An important component of the soil that will influence the created wetland's success is the seed bank. Seed banks can be transferred from nearby or prerestoration wetlands by depositing the top $15-30 \mathrm{~cm}$ (6-12 inches) of soil as the surface horizon, or taking plugs or cores from other wetlands. Microbes, seeds, and organisms will be transferred in the soil as well during this process (Lowry 1990, Mitsch and Gosselink 2000).

Ensuring successful vegetation in wetlands is accomplished through various methods besides deposition of wetland soils for its seed bank, such as introduced plantings, natural succession, and a combination of plantings and natural processes. The techniques of vegetation introduction are commonly referred to as either "designer" or "self-design." Designer wetlands are planted and expected to remain unchanged; selfdesign includes multiple seedings, transplants, and an open system to allow natural processes to recruit new species and retain the most appropriate introductions (Odum 1989, Mitsch 1993, Mitsch and Wilson 1996). If plants, tubers, or rhizomes are used, they should be obtained from nearby sources and not detrimental to the source wetland, or from wild stock propagated at local nurseries (Lowry 1990, Mitsch and Gosselink 2000). As studies compare the success of designer and self-design wetlands, multiple 
opportunities for vegetation development through multiple planting techniques and an open system appear to be most successful (Reinartz and Warne 1993, Mitsch and Wilson 1996).

Physical monitoring of the trend toward the wetland type or function is the fourth stage; once the site meets the performance criteria, regulatory certification is provided. Mandatory monitoring to measure success of mitigated wetlands is minimal (Race and Fonseca 1996, NRC 2001), with once or twice a year monitoring of simplistic measures such as percent plant cover, animals observed, and amount of surface water (Mitsch and Wilson 1996). Although plant cover is a common, easy monitoring method, it may be a poor indicator of function (Reinartz and Warne 1993, Mitsch and Wilson 1996). In addition to hydrological parameters, other ecological factors such as plant communities or avian composition may be important in assessing wetland function (NRC 2001). But the function of wildlife value is rarely measured because it is more resource intensive than percent surface water or plant cover (NRC 2001, Mitsch and Wilson 1996). Several scientific studies have focused on avian (Hickman 1994, van Rees-Siewert and Dinsmore 1996, Melvin and Webb 1998, Davis et al. 2008, O’Neal et al 2008) and amphibian species composition (Funk and Dunlap 1999, Monello and Wright 1999, Lehtinen 2001) to assess wetland function. Other studies have investigated invertebrate communities in constructed verses reference wetlands (Streever et al. 1996, Balcombe 2005b).

Mitsch and Wilson (1996) suggest three requirements for successful creation: understand function, use natural self-design, and allow sufficient time. Regulatory agencies usually discontinue the monitoring requirement by year five, which assumes the wetland is essentially established (Zedler 1996, Snodgrass et al. 2000, Campbell et al. 
2002). But freshwater marshes may require closer to 20 years to fully reach functional and ecological development (Mitsch and Wilson 1996). Functional replacement is rarely achieved (Race 1985, Erwin 1991, NRC 1992, Brinsen and Reinhardt 1996).

The final stage in the mitigation process is verification of protection in perpetuity. Besides protection of the site over time, permanence also refers to "long-term sustainability in a changing landscape" (NRC 2001). Future risks to the wetland's ability to provide services are rarely considered (Boyd and Wainger 2002). Although succession could be expected to revegetate the prevalent open-water wetlands, only $2 \%$ of openwater wetlands were reclassified into emergent marsh between the 1997 and 2005 Status and Trends of Wetlands reports (Dahl 2000, Dahl 2006). Better enforcement and permit compliance is needed to ensure quality of mitigation replacements (Redmond 1992, Race and Fonseca 1996).

Not all created or restored wetlands are compensatory mitigation. The gap in successful 404 mitigations and losses of non-jurisdictional wetlands is partially counteracted with voluntary wetland constructions on public and private lands. Over $85 \%$ of wetlands are on private lands (CEQ 2006). Federal programs that encourage private landowners to voluntarily construct or restore wetlands include the Wetlands Reserve Program, Partners for Fish and Wildlife, Conservation Reserve Program, and Conservation Reserve Enhancement Program (CEQ 2006, O'Neal et al. 2008). The United States Department of Agriculture offers several financial incentive programs for private landowners to restore wetlands. The Wetland Reserve Program (WRP) has protected over 720,000 ha of wetlands (Rewa 2005), and the Conservation Reserve Enhancement Program (CREP) has enrolled over 37,000 ha in wetlands (Allen 2005, 
O'Neal et al. 2008). The Fish and Wildlife Service also offers federal funds through the Partners for Wildlife program to encourage private landowners to improve wildlife habitats, including restoration of wetlands. There are 303,415 wetland ha (750,000 acres) enrolled in Partners for Wildlife with 37,000 landowner agreements (CEQ 2006). Similar to compensatory mitigation, success is usually evaluated by measures of hydrology and hydrophytic vegetation (O'Neal 2003, Richards and Grabow 2003, Wanhong et al. 2005, O'Neal et al. 2007). The success of CREP wetlands in the Illinois River watershed was examined as a function of quality habitat for waterbirds, though few other studies of the habitat functions of voluntary wetlands exist (O’Neal and Heske 2007).

\section{Acoustical Sampling}

With the improved technology of bat detectors and associated software, many studies now utilize acoustical monitoring, either alone or in conjunction with mist netting (Fenton et al. 1977, Bell 1980, Fenton et al. 1983, Crome et al. 1988, O'Farrell 1997, Vaughan et al. 1997). Acoustical monitoring can sample a larger area than mist netting (O'Farrell et al. 1999) to assess relative activity, bat community composition, and general vegetation associations (Thomas and West 1989, Johnson et al. 2002, Menzel et al. 2003, Miller et al. 2003, Brooks and Ford 2005).

Sampling with bat detectors can be conducted either passively or actively. Passive recording is conducted by placing the Anabat (Titley Electronics, Ballina, Australia) recorder, attached to an AnaBat Compact Flash data storage module, in a stationary position where it will record continuously throughout the night or repeat recording over a fixed period each night (Hayes and Hounihan 1994, Hayes and Adam 1996, Krusic et al. 1996, Perdue and Steventon 1996). Bats may fly outside of the 
limited cone area or pass through it too quickly to adequately record an individual's call. Level of clutter and differences in flight patterns above canopies can also affect detection among species (Johnson et al. 2002). In contrast, active monitoring involves either monitoring while the researcher is moving, or remaining stationary and sweeping the detector through the air to focus on areas of concentrated bat activity. Active monitoring is superior to passive monitoring due to enhanced quality of calls, higher volumes of data, and a better representation of bat species richness (O'Farrell et al. 1999, Johnson et al. 2002).

Acoustical monitoring can yield important information not easily gleaned from mist netting, can be a vital tool for assessing presence and relative indices of activity, and may serve as the basis for additional focused studies (Gannon et al. 2003). O'Farrell and Gannon (1999) compared acoustical monitoring versus capture techniques for conducting inventories of bats in the southwestern United States. They captured only $63.5 \%$ of the species present using nets or harp traps, compared to $86.9 \%$ of the species present using an Anabat II ultrasonic detector (Titley Electronics, Ballina, Australia). This difference is important to note because acoustical sampling allows the sampling of bats that usually fly above net level, such as hoary bats or those that are using flight paths that do not coincide with the nets. The ability to detect these species is therefore useful in surveying bat communities (Johnson et al. 2002), as long as limitations are considered.

\section{Akaike's Information Criterion}

Null hypothesis testing, and the use of associated p-values, has limitations in the biological sciences due to several inherent flaws. The null hypothesis is false a priori, often trivial, and associated with a single alternative hypothesis (Chamberlin 1965, 
Burnham and Anderson 2002). With a large enough sample size, one can always reject a null hypothesis (Anderson et al. 2000). Furthermore, the alpha level, based on conventional values, is arbitrary and forces a decision (reject or not reject), when the issue should be estimation of the size of an effect or strength of evidence (Royall 1997, Anderson et al. 2000). Null hypothesis testing does not allow for measuring the evidence for multiple models, nor provide an estimate of precision. Stepwise procedures are likewise problematic with model selection uncertainty (McQuarrie and Tsai 1998).

In contrast, the information theoretic methods allow a more extended analysis of multiple working hypotheses based on evidence, not significance, where the goal is to find the best model(s) in a set (Burnham and Anderson 2002). The information theoretic approach is a multi-model selection theory that bases inferences on the entire set, and can utilize model averaging using Akaike weights (Burnham and Anderson 1998). The information criteria (AIC, AICc, QAIC) are estimators of relative Kullback-Leibler information, from which the inference is based upon (Kullback and Leibler 1951, Burnham and Anderson 2002). This allows for a more in-depth analysis of models, including estimates of precision to examine model selection uncertainty.

Models are generated a priori based on literature review and the species natural history traits. A global model containing all variables is created, as well as subsequent models that subset these variables based on alternative hypotheses. Specification of too many possible models, or "data dredging," is to be avoided (Burnham and Anderson 1998).

Candidate models are ranked according to their $\mathrm{AIC}_{c}$ values, with the smallest value approximating the best model. Models with $\mathrm{AIC}_{\mathrm{c}}$ differences $\leq 2$ are considered 
supported. The Akaike weight $\left(\omega_{i}\right)$ estimates the probability that a particular model is the best model in the candidate set and therefore estimates the relative importance of the individual parameters (Burnham and Anderson 2002).

\section{LITERATURE CITED}

Agosta. S.J. and D. Morton. 2003. Diet of the big brown bat, Eptesicus fuscus, from Pennsylvania and Western Maryland. Northeastern Naturalist 10(1): 89-104. Aldridge, H.D. and I.L. Rautenach. 1987. Morphology, echolocation, and resource partitioning in insectivorous bats. Journal of Animal Ecology 56: 763-778.

Allen, A. W. 2005. The Conservation Reserve Enhancement Program. Pages 115-134 in J. B. Haufler, editor. Fish and wildlife benefits of Farm Bill conservation programs: 2000-2005 update. The Wildlife Society Technical Review 05-2, Bethesda, Maryland, USA.

Anderson, D.R. and K. P. Burnham. 2002. Avoiding pitfalls when using informationtheoretic methods. The Journal of Wildlife Management 66(3): 912-918.

Arnett, E.B. 2003. Advancing science and partnerships for the conservation of bats and their habitats. Wildlife Society Bulletin 31:2-5.

Balcombe, Collin K., J.T. Anderson, R.H. Fortney, J.S. Rentch, W.N. Grafton, and W.S. Kordek. 2005. Aquatic macroinvertebrate assemblages in mitigated and natural wetlands. Hydrobiologia 541: 165-188.

Baker, M.D. and M.J. Lacki. 2006. Roosting habitat of the long-legged Myotis in Ponderosa pine forests. . Journal of Wildlife Management 70: 207-215.

Barbour, R.W. and W.H. Davis. 1969. Bats of America. University of Kentucky Press, Lexington. $286 \mathrm{pp}$. 
Barclay, R.M.R. 1985. Long verses short-range foraging strategies of hoary (Lasiuris cinereus) and silver-haired (Lasionycteris noctivagens) bats and the consequences for prey selection. Canadian Journal of Zoology 63: 2507-2515.

Bedford, B.L. 1996. The need to define hydrologic equivalence at the landscape scale for freshwater wetland mitigation. Ecological Applications 6:57-68.

Bedford, B.L. and K. Godwin. 2003. Fens of the United States: distribution, characteristics, and scientific connection versus legal isolation. Wetlands. 23:608-629.

Bell, G.P. 1980. Habitat use and response to patches of prey by desert insectivorous bats. Canadian Journal of Zoology, 58: 1876-1883.

Bellwood, J.J., and M.B. Fenton. 1976. Variation in the diet of Myotis lucifugus (Chiroptera: Vespertilionidae). Canadian Journal of Zoology 54:1674-1678.

Boyd, J.L. and L. Wainger. 2002. Landscape indicators of ecosystem service benefits. American Journal of Agricultural Economics 84 (5): 1371-1378.

Brack, V.W., Jr. 1983. The nonhibernating ecology of bats in Indiana with emphasis on the endangered Indiana bat, Myotis sodalis. West Lafayette, IN: Purdue University. 280 p. Ph.D. dissertation.

Brigham, R.M. and Fenton, M.B. 1991. Convergence in foraging strategies by two morphologically and phylogenetically distinct nocturnal aerial insectivores. Journal of Zoology 223: 475-489.

Brinson, M.M., W. Kruczynski, L.C. Lee, W.L. Nutter, R.D. Smith, and D.F. Whigham. 1994. Developing an approach for assessing the functions of wetlands. Pages 615- 
624 in W. J. Mitsch, editor. Global wetlands: Old World and New. Elsevier Science, Amsterdam, Netherlands.

Brinsen and Reinhardt. 1996. The role of reference wetlands in functional assessment and mitigation. Ecological Applications 6 (1): 69-76.

Brooks, R.T., and W. M. Ford. 2005. Bat Activity in a Forest Landscape of Central Massachusetts. Northeastern Naturalist 12(4):447-462.

Burnham, K.P. and D.R. Anderson. 1998. Model selection and inference: a practical information-theoretic approach. Springer-Verlag, New York, NY, USA.

Burnham, K.P. and D.R. Anderson. 2002. Model selection and multi-model inference: a practical information-theoretic approach. Second edition. Springer-Verlag, New York, USA.

Campbell, Deborah A, C.A. Cole, R.P. Brooks. 2002. A comparison of created and natural wetlands in Pennsylvania, USA. Wetlands Ecology and Management Vol. 10, Issue 1, pp: $41-49$.

Chamberlin, T. C. 1965. The method of multiple working hypotheses. Science 148:754759. [Reprint of 1890 paper in Science.]

Clark, B.K., Bowles, J.B., and B.S. Clark. 1987. Summer status of the endangered Indiana bat in Iowa. American Midland Naturalist 118: 32-39.

Cole, A.C. and D. Shafer. 2002. Section 404 wetland mitigation and permit success criteria in Pennsylvania, USA,1986-1999. Environmental Management 30: 50815.

Cope, J.B. and S.R. Humphrey. 1977. Spring and autumn swarming behavior in the Indiana bat, Myotis sodalis. Journal of Mammalogy 58(1): 93-95. 
Council on Environment Quality. 2005. Conserving America's Wetlands: Implementing the President's Goal. Executive Office of the President, Washington, D.C.

Council on Environment Quality. 2006. Conserving America's Wetlands 2006: Two years of progress implementing the President's goal. Executive Office of the President, Washington, D.C.

Cowardin, L.M., V. Carter, F.C. Golet, and E.T. LaRoe. 1979. Classification of wetlands and deepwater habitats of the United States. U.S. Department of the Interior, Fish and Wildlife Service, Washington, DC. FWS/OBS-79/31.

Crampton, L.H. and R.M.R. Barclay. 1998. Selection of roost and foraging habitat by bats in different-aged mixed aspen mixedwoods stands. Conservation Biology 12:1347-1358.

Crome, F.H.J, and Richards, G.C. 1988. Bats and gaps: microchiropteran community structure in a Queensland rain forest. Ecology. 69:1960-1969.

Cryan, P.M., M.A. Bogan, and G.M. Yanega. 2001. Roosting habits of four bat species in the Black Hills of South Dakota. Acta Chiropterologica 3:43-52.

Dahl, T.E. 2000. Status and trends of wetlands in conterminous United States 1986 to 1997. U.S. Department of the Interior, Fish and Wildlife Service, Washington, D.C.

Dahl, T.E. 2006. Status and trends of wetlands in the conterminous United States 1998 to 2004. U.S. Department of the Interior; Fish and Wildlife Service, Washington, D.C. $112 \mathrm{pp}$. 
Davis, D.E., C. H. Hanson, and R. B. Hansen. 2008. Constructed Wetland Habitat for American Avocet and Black-Necked Stilt Foraging and Nesting. Journal of Wildlife Management 72(1):143-151; 2008.

Erwin, K. 1991. An evaluation of wetland mitigation in the South Florida Water Management District, West Palm Beach, Florida, USA.

Fasola, M., and X. Ruiz. 1996. The value of rice fields as substitutes for natural wetlands for waterbirds in the Mediterranean region. Colonial Waterbirds, 19 (Special publication 1): 122-128.

Fenton, M.B. 1969. Summer activity of Myotis lucifugus at hibernacula in Ontario and Quebec. Canadian Journal of Zoology 47: 597-602.

Fenton, M. B.; N. G. H. Boyle; T. M. Harrison; D. J. Oxley. 1977. Activity Patterns, Habitat Use, and Prey Selection by Some African Insectivorous Bats. Biotropica, Vol. 9, No. 2. pp. 73-85.

Fenton, M.B., H.G. Merriam, and G.L. Holroyd. 1983. Bats of Kootenay, Glacier, and Mount Revelstoke national parks in Canada: identification by echolocation calls, distribution, and biology. Canadian Journal of Zoology, 61:2503-2508.

Fenton, M.B. and G.K. Morris. 1976. Opportunistic feeding by desert bats (Myotis spp.). Canadian Journal of Zoology 54: 526-530.

Fergus, C. Bats. 2002. Wildlife Notes 175-35, PA Game Commission, Division of Information and Education, Harrisburg PA.

Ford, W.M., M.A. Menzel, J.L. Rodrigue, J.M. Menzel and J.B. Johnson. 2005. Relating bat species presence to simple habitat measures in a central Appalachian forest. Biological Conservation 126: 528-539. 
Ford, W.M., J.M. Menzel, M.A. Menzel, J.W. Edwards, and J.C. Kilgo. 2006. Presence and absence of bats across habitat scales in the Upper Coastal Plain of South Carolina. Journal of Wildlife Management 70(5): 1200-1209.

Francl, K. E., W. M. Ford, and S. B. Castleberry. 2004. Characterization of high elevation central Appalachian wetlands. Res. Pap. NE-725. Newton Square, PA: U.S. Department of Agriculture, Forest Service, Northeastern Research Station. $26 \mathrm{p}$.

Francl K. 2008. Summer bat activity at woodland seasonal pools in the northern Great Lakes region. Wetlands 28(1): 117-124.

Flaquer, C., X. Puig-Montserrat, U. Goiti, F. Vidal, A. Curco, and D. Russo. 2009. Habitat selection in Nathusius' pipistrelle (Pipistrellus nathusii): the importance of wetlands. Acta Chiropterologica 11(1): 149-155.

Funk, W.C. and W.W. Dunlap. 1999. Colonization of high-elevation lakes by longtoed salamanders (Ambystoma macrodactylum) after extinction of introduced trout populations. Canadian Journal of Zoology 77: 1759-1767.

Furlonger, C.L, H.J. Dewar, M.B. Fenton. 1987. Habitat use by foraging insectivorous bats. Can J Zool 65:284-288.

Gannon, W.L., R.E. Sherwin, and S. Haymond. 2003. On the importance of articulating assumptions when conducting acoustic studies of habitat use by bats. Wildlife Society Bulletin 31(1):45-61.

Gladwin, D., and J. Roelle. 1992. Nationwide permits: case studies highlight concerns. National Wetlands Newsletter 14(2):7-9. 
Grindal, S.D., Morissette J.L., and Brigham, R.M. 1999. Concentration of bat activity in riparian habitats over an elevational gradient. Canadian Journal of Zoology 77: 972-977.

Hall, J.S. 1962. A life history and taxonomic study of the Indiana bat, Myotis sodalis. Reading Public Mus. And Art Gallery, Sci. Publ., 12:1-68.

Hamilton, I.M., and R.M.R. Barclay. 1998. Diets of juvenile, yearling, and adult big brown bats (Eptesicus fuscus) in southwestern Alberta. Journal of Mammalogy 79:764-771.

Hart, J.A., G.L. Kirkland, Jr., and S.C. Grossman. 1993. Relative abundance and habitat use by tree bats, Lasiurus spp., in southern Pennsylvania. Canadian Field Naturalist 107: 208-212.

Harvey, M.J. 1997. Status of bats in the United States. American Caves 10(1): 10-13. Harvey, M.J., J.S. Altenbach, and T.L. Best. 1999. Bats of the United States. Arkansas Game and Fish Commission, Little Rock, Arkansas, USA.

Hayes, J.P. and M.D. Adam. 1996. The influence of logging riparian areas on habitat utilization by bats in western Oregon. Pages 228-237 in R.M.R. Barclay and R.M. Brigham, editors. Bats and Forests Symposium, October 19-21, 1995, Victoria, British Columbia, Canadian Research Branch, B.C. Ministry of Forests, Victoria, B.C. Working Group.

Hayes, J.P. and P. Hounihan. 1994. Field use of the Anabat II bat detector system to monitor bat activity. Bat Research News 35:1-3.

Heaven, J. B., F. E. Gross, and A. T. Gannon. 2003. Vegetation comparison of a natural and a created emergent marsh wetland. Southeastern Naturalist 2(2): 195-206. 
Hickman, S. 1994. Improvement of habitat quality for nesting and migrating birds at the Des Plaines River wetlands demonstration project. Ecological Engineering 3:485494.

Hogberg, L.K., K.J. Patriquin, and R.M.R. Barclay. 2002. Use by bats of patches of residual trees in logged areas of boreal forest. American Midland Naturalist 148:282-288.

Huie, K.M. 2002. Use of constructed woodland ponds by bats in the Daniel Boone National Forest. M.S. Thesis. Eastern Kentucky University, KY, USA.

Humphrey, S.R., A.R Richter, and J.B. Cope. 1977. Summer habitat and ecology of the endangered Indiana bat, Myotis sodalis. Journal of Mammalogy 58: 334-346.

Imes, R. 1992. The Practical Entomologist. Simon and Schuster, Inc. New York, NY, USA.

Johnson, J.B., M.A. Menzel, J.W. Edwards, and W.M. Ford. 2002. A comparison of 2 acoustical bat survey techniques. Wildlife Society Bulletin 30(3): 931-936.

Jung, T.S., I.D. Thompson, R.D. Titman and A.P. Applejohn. 1999. Habitat selection by forest bats in relation to mixed-wood stand types and structure in central Ontario. Journal of Wildlife Management 63:1306-1319.

Kentula, M.E., Brooks, R.P., Gwin, S.E., Holland, C.C., Sherman, A.D. and Sifneos, J.C. 1992. An approach to improving decisionmaking in wetland restoration and creation. In: Hairston, J.A. (ed.), U.S. Environmental Protection Agency, Environmental Research Lab, Corvallis, OR, USA. 
Kentula, M.E., S.E. Gwin, S.M. Pierson. 2004. Tracking changes in wetlands with urbanization: sixteen years of experience in Portland, Oregon, USA. Wetlands 24:734-43.

Kettlewell, C. 2005. An inventory of Ohio wetland compensatory mitigation, Part 2. Ohio Environmental Protection Agency, Division of Surface Water, Wetland Ecology Group, Final Report to U.S. EPA Grant No. CD97576201-0, Columbus, $\mathrm{OH}$.

Kettlewell, C., V. Bouchard, D. Porej, M. Michaccion, J.J. Mack, D. White, and L. Fay. 2008. An assessment of wetland impacts and compensatory mitigation in the Cuyahoga River watershed, Ohio, USA. Wetlands 28(1): 57-67.

Krusic, R.A., M. Yamasaki, C.D.Neefus, and P.J. Perkins. 1996. Bat habitat use in White Mountain National Forest. Journal of Wildlife Management 60:625-631.

Kullback, S.. and A. Leibler. 1951. On information and sufficiency. Annals of Mathematical Statistics 22:79-86.

Kunz, T. H. 1973. Resource utilization: temporal and spatial components of bat activity in central Iowa. Journal of Mammalogy 54:14-32.

Kurta, A. and J.O. Whitaker. 1998. Diet of the endangered Indiana bat (Myotis sodalis) on the northern end of its range. American Midland Naturalist 140: 280-286.

Kusler, J. Esq. 2004. The SWANCC decision: state regulation of wetlands to fill the gap. Association of State Wetland Managers. http://www.aswm.org/swp/the SWANCCdecision9.pdf.

Lehtinen, Richard M. and S. M. Galatowitsch. 2001. Colonization of restored wetlands by amphibians in Minnesota. American Midland Naturalist 145 (2): 388-396. 
Limpens, H. J. G. A., W. Helmer, A. Van Winden, and K. Mostert. 1989. Bats

(Chiroptera) and linear landscape elements: a review of our pre- sent knowledge of the importance of linear land- scape elements to bats. Lutra 32:1-20.

Lowry, Dennis J. 1990. Restoration and creation of palustrine wetlands associated with riverine systems of the glaciated northeast. In Wetland Creation and Restoration: the status of the science. Editors Jon A. Kusler and Mary E. Kentula. Island Press.

MacSwiney, M. C., B.B. Cime, F.M. Clarke, P.A. Racey. 2009. Insectivorous bat activity at cenotes in the Yucatan Peninsula, Mexico. Acta Chiropterologica 11(1): 139-147.

Magee, T.K., T.L.Ernst, M.E. Kentula, and K. A. Dwire 1999. Floristic comparison of freshwater wetlands in an urbanizing environment. Wetlands 19(3):517-534.

McCracken, G.F. 1989. Cave conservation: special problems of bats. National Speleological Society Bulletin 51: 49-51.

McQuarrie, A. D. R., A .L. TSAI. 1998. Regression and time series model selection. World Scientific, Singapore.

Melvin, S.L., and J.W.Webb. 1998. Differences in the avian communities of natural and created Spartina alterniflora salt marshes. Wetlands 18(1):59-69.

Menzel, J.M., M.A. Menzel, J.C. Kilgo, W.M. Ford and J.W. Edwards. 2005. Bat response to Carolina bays and wetland restoration in the southeastern U.S. Coastal Plain. Wetlands Journal 25:542-550.

Menzel, M.A., J.M. Menzel, T.C. Carter, W.M. Ford, and J.W. Edwards. 2001. Review of the forest habitat relationships of the Indiana bat (Myotis sodalis). Gen. Tech. 
Rep. NE-284. Newton Square, PA: U.S. Department of Agriculture, Forest Service, Northeastern Research Station.

Menzel, M. A, Menzel, J.M, Kilgo, J.C., (and others). 2003. Bats of the Savannah River site and vicinity. Gen. Tech. Rep. SRS-68. Asheville, N.C., US Department of Agriculture, Forest Service, Southern Research Station. 69p.

Merritt, J.F. 1987. Guide to the mammals of Pennsylvania. University of Pittsburgh Press, Pittsburgh PA. 408 pp.

Miller, Darren A., Edward B. Arnett, and Michael J Lacki. 2003. Habitat Management for forest-roosting bats of North America: a critical review of habitat studies. Wildlife Society Bulletin 2003 31(1): 30-44.

Mitsch, W.J. 1993. Ecological engineering - a cooperative role with the planetary lifesupport systems. Environmental Science and Technology. 27:438-445.

Mitsch, W.J., and J.G. Gosselink. 2000. Wetlands, Third edition. Wiley and Sons, New York, New York, 920pp.

Mitsch, William H. and R.F. Wilson. 1996. Improving the success of wetland creation and restoration with know-how, time, and self-design. Ecological Applications 6(1): 77-83.

Monello, R.J. and R.G. Wright. 1999. Amphibian habitat preferences among artificial ponds in the Palouse region of northern Idaho. Journal of Herpetology 33:298303.

National Wetlands Policy Forum. 1988. Protecting America's wetlands: an action agenda. Conservation Foundation, Washington, D.C., USA. 
National Research Council. 1992. Restoration of aquatic ecosystems: science, technology, and public policy. National Academy Press, Washington D.C., USA. National Research Council. 1995. Wetlands: Characteristics and boundaries. Committee on Characterization of Wetlands, Water Science and Technology Board. National Academy Press, Washington, D.C. 268 p.

National Research Council. 2001. Compensating for Wetland Losses under the Clean Water Act. Washington DC: National Academy Press.

Odum, H.T. 1989. Ecological Engineering and self-organization. Pages 79-101 in W.J. Mitsch and S.E. Jorgensen, editors. Ecological engineering: an introduction to ecotechnology. Wiley Interscience, New York, New York, USA.

O'Farrell, M.J. 1997. Use of echolocation calls for the identification of free-flying bats. Transactions of the Western Section of the Wildlife Society, 33:1-8.

O'Farrell, M.J., B.W. Miller, and W.L. Gannon. 1999. Qualitative identification of freeflying bats using the Anabat detector. Journal of Mammalogy 80:11-23.

O’Farrell, Michael J. and W. L. Gannon. 1999. A comparison of acoustic versus capture techniques for the inventory of bats. Journal of Mammalogy, 80(1): 24-30.

O’Neal, B. J. 2003. Wetland habitat in the Conservation Reserve Enhancement Program: monitoring and predicting use by migrant and resident waterbirds. Thesis, University of Illinois Urbana-Champaign, Champaign, USA.

O'Neal, B. J., and E. J. Heske. 2007. Characterization of wetlands in the Conservation Reserve Enhancement Program in Illinois. Transactions of the Illinois State Academy of Science, Springfield, USA. 
O’Neal, B.J., E.J. Heske, and J.D. Stafford. 2008. Waterbird response to wetlands restored through the conservation reserve enhancement program. Journal of Wildlife Management 72(3): 654-664.

O’Shea, T.J., Bogan, M.A., and L.E. Ellison. 2003. Monitoring trends in bat populations of the United States and territories: status of the science and recommendations for the future. Wildlife Society Bulletin 31(1): 16-19.

Osmond, D.L., D.E. Line, J.A. Gale, et al. 1995. WATERSHEDSS: water, soil, and hydroenvironmental decision support system. Available at http://h2osparc.wq.ncsu.edu.

Owen, S.F., M.A. Menzel, J.W. Edwards, W.M. Ford, J.M. Menzel, B.R. Chapman, P.B. Wood and K.V. Miller. 2004. Bat activity in harvested and intact forest stands in the Allegheny Mountains. Northern Journal of Applied Forestry 21:154-159.

Perdue, M. and J.D. Steventon. 1996. Partial cutting and bats: a pilot study. Pages 273276 in R.M.R. Barclay and R.M. Brigham, editors. Bats and Forests Symposium, October 19-21, 1995, Victoria, British Columbia, Canadian Research Branch, B.C. Ministry of Forests, Victoria, B.C. Working Paper 23/1996.

Pierson, E.D. 1999. Tall trees, deep holes, and scarred landscapes: conservation biology of North American bats. Pages 309-325 in T.H. Kunz, and P. Racey, editors. Bat biology and conservation. Smithsonian Institution Press, Washington D.C., USA. Porej, D. 2003. An inventory of Ohio wetland compensatory mitigation, Part 1. Ohio Environmental Protection Agency, Division of Surface Water, Wetland Ecology Group, Final Report to U.S. EPA Grant No. CD97576201-0, Columbus, OH. 
Race, M.S. 1985. Critique of present wetlands mitigation policies in the United States based on an analysis of past restoration projects in San Francisco Bay. Environmental Management 9: 71-82.

Race, M.S. and M.S. Fonseca. 1996. Fixing compensatory mitigation: what will it take? Ecological Applications 6(1): 94-101.

Ramsar Convention Secretariat. 2007. Wise use of wetlands: A conceptual framework for the wise use of wetlands. Ramsar handbooks for the wise use of wetlands. $3^{\text {rd }}$ Edition. Ramsar Convention Secretariat, Gland, Volume 1, 26 pp.

Redmond, A. 1992. How successful is mitigation? National Wetlands Newsletter 14(1):5-6.

Reinartz, J.A. and E.L. Warne. 1993. Development of vegetation in small created wetlands in southeast Wisconsin. Wetlands 13:153-164.

Rewa, C. 2005. Wildlife benefits of the Wetlands Reserve Program. Pages 133-146 in J. B. Haufler, editor. Fish and wildlife benefits of Farm Bill conservation programs: 2000-2005 update. The Wildlife Society Technical Review 05-2, Bethesda, Maryland, USA.

Richards, R. P., and G. L. Grabow. 2003. Detecting reductions in sediment loads associated with Ohio's Conservation Reserve Enhancement Program. Journal of the American Water Resources Association 39: 1261-1268.

Roberts, T.H. 1991. Habitat value of man-made coastal marshes in Florida. Technical Report WRP-RE-2. Vicksburg, MS: U.S. Army Engineer Waterways Experiment Station. 
Royall, R. M. 1997. Statistical evidence: a likelihood paradigm. Chapman \& Hall, London, United Kingdom.

Russo, D., and G. Jones. 2003. Use of foraging habitat by bats in a Mediterrean area determined by acoustic surveys: conservation implications. Ecography 26: 197209.

Russo D., D. Almenar, J. Aihatza, U. Goiti, E. Salsamendi, and I. Garin. 2005. Habitat selection in sympatric Rhinolophus mehelyi and R. euryale (Chiroptera: Rhinolophidae) in Spain. Journal of Zoology (London), 266: 327-332.

Schirmacher, M.R., S.B. Castleberry, W.M. Ford, and K.V. Miller. 2007. Habitat Associations of Bats in south-central West Virginia. Proceedings of Annual Conference of Southeast Association Fish and Wildlife Agencies 61:46-52.

Shump, K.A, and Shump, A.U. 1982a. Lasiurus borealis. Mammalian Species. 183:16.

Snell-Rood, E.C. and D. A. Cristol. 2003. Avian communities of created and natural wetlands: bottomland forests in Virginia. The Condor. 105:303-315.

Snodgrass, Joel W., M.J. Komoroski, A. L. Bryan Jr., and J. Burger. 2000. Relationships among isolated wetland size, hydroperiod, and amphibian species richness: implications for wetland regulations. Conservation Biology, 14(2): 414-419.

Streever, W.J., K.M. Portier, and T.L. Crisman. 1996. A comparison of dipterans from ten created and ten natural wetlands. Wetlands 16: 416-428.

Streever, W.J. 2000. Spartina alterniflora marshes on dredged material: a critical review of the ongoing debate over success. Wetlands Ecological Management 8(5):295316. 
The Conservation Foundation. 1988. Protecting America's wetlands: an action agenda.

Final Report of the National Wetlands Policy Forum. Washington, D.C.

Thomas, D. W. and S. D. West. 1989. Sampling methods for bats. United States Forest Service General Technical Report PNW-243:1-20.

Tuttle, M.D. 1997. The world of bats. Pp. 5-16 in America's Neighborhood Bats. University of Texas Press, Texas, U.S.A.

USACE (U.S. Army Corps of Engineers). 1987. Corps of Engineers wetland delineation manual, Technical Report Y-87-1. U.S. Army Corps of Engineer Waterways Experiment Station, Vicksburg, MS, USA.

USACE (U.S. Army Corps of Engineers). 2000. Mitigation Guidelines and Monitoring Requirements. Special Public Notice 97-00312-SDM. Los Angeles District, U.S. Army Corps of Engineers, Los Angeles, CA.

USACE/EPA (U.S. Army Corps of Engineers and U.S. Environmental Protection Agency). 1990. Memorandum of Agreement Between the Environmental Protection Agency and Department of the Army Concerning the Determination of Mitigation Under the Clean Water Act Section 404 (b)(1) Guidelines. February 8, 1990.

USACE/EPA (U.S. Army Corps of Engineers and U.S. Environmental Protection Agency). 2008a. Clean Water Act Jurisdiction following the U.S. Supreme Court's decision in Rapanos v. United States and Carabell v. United States. December 2, 2008.

USACE/EPA (U.S. Army Corps of Engineers and U.S. Environmental Protection Agency). 2008b. Response to comments "Clean Water Act Jurisdiction following 
the U.S. Supreme Court's decision in Rapanos v. United States and Carabell v. United States guidance" December 2, 2008.

van Rees-Siewert, K.L., and J.J. Dinsmore. 1996. Influence of wetland age on bird use of restored wetlands in Iowa. Wetlands 16(4):577-582.

Van Zyll de Jong, C.G. 1985. Bats. National Museums of Canada. Ottawa. 212 pp.

Vaughan, Nancy; Gareth Jones; Stephen Harris. 1997. Habitat Use by Bats (Chiroptera) Assessed by Means of a Broad-Band Acoustic Method. The Journal of Applied Ecology, Vol. 34, No. 3. pp. 716-730.

Von Frenckell, B., and R. M. R. Barclay. 1987. Bat activity over calm and turbulent water. Canadian Journal of Zoology 65:219-222.

Vonhof, M.J. and R.M.R. Barclay. 1996. Roost site selection and roosting ecology of forest-dwelling bats in Southern British Columbia. Canadian Journal of Zoology 74: 1797-1805.

Waldien, D.L., J.P. Hayes, and E.B. Arnett. 2000. Day roosts of female long-eared myotis in Western Oregon. Journal of Wildlife Management 61: 674-684.

Walsh, A.L. and Harris S. 1996. Factors determining the abundance of vespertilinoid bats in Britain: geographical, land class, and local habitat relationships. Journal of Applied Ecology 33: 513-529.

Wanhong, Y., M. Khanna, R. Farnsworth, and H. O “ nal. 2005. Is geographical targeting cost-effective? The case of the Conservation Reserve Enhancement Program in Illinois. Review of Agricultural Economics 27:70-88.

Want, W.L. 1994. Law of Wetlands Regulation. Deerfield, IL: Clark Boardman Callaghan. 
Whitaker, J.O., Jr. 1995. Food of the big brown bat Eptesicus fuscus from maternity colonies in Indiana and Illinois. American Midland Naturalist 134:346-360.

Whitaker, John O. 2004. Prey selection in a temperate zone insectivorous bat community. Journal of Mammalogy 85: 460-469.

Wilhide, J.D., M.J. Harvey, V.R. McDaniel, and V.E. Hoffman. 1998. Highland pond utilization by bats in the Ozark National Forest, Arkansas. Journal of the Arkansas Academy of Science 52:110-112.

Zedler, J.B. 1990. A Manual for Assessing Restored and Natural Coastal Wetlands with Examples from Southern California. Report. No. T-CSGCP-021. La Jolla: California Sea Grant College.

Zedler, Joy B. 1996. Ecological issues in wetland mitigation: an introduction to the forum. Ecological Applications, 6(1): 33-37.

Zimmerman, G.S., and W.E. Glanz. 2000. Habitat use by bats in eastern Maine. Journal of Wildlife Management 64:1032-1040. 


\section{Chapter 3}

\section{Bat Use of Created and Natural Wetlands}

(Formatted in style of Journal of Wildlife Management) 
13 October 2009

Marcia Pradines Maslonek

Division of Forestry and Natural Resources

West Virginia University 26506

304-433-6331; E-mail mmaslonek@gmail.com

RH: Bat Use of Constructed and Natural Wetlands - Maslonek et al.

\section{BAT USE OF CREATED AND NATURAL WETLANDS}

MARCIA PRADINES MASLONEK, Division of Forestry and Natural Resources, West Virginia University, Morgantown, WV 26506, U.S.A.

Abstract: In theory, compensatory wetland mitigation is designed to offset the loss of specific wetland functions and associated values, including wildlife habitat, resulting from dredging and filling of wetlands under the Clean Water Act. Issues preventing offset success include failure to replace functions, lack of protection for isolated and small wetlands, and conversion of emergent wetlands to open water ponds. Most research on wildlife functions in these wetlands has been limited to birds, amphibians, plants, and insects. However, wetlands also are important for mammals, particularly bats. I conducted acoustic surveys at 79 created and natural wetlands in western Pennsylvania and eastern Ohio to determine bat species presence, richness, and a relative index of activity by bat species. I developed a priori models of wetland design and landscape characteristics for analysis through an information theoretic approach. The landscape characteristics surrounding the wetland predicted presence and influenced activity in all bat species studied, except for activity of eastern pipistrelles (Pipistrellus subflavus), which was influenced by the origin of the wetland. The particular response to each landscape type varied by bat species based on differences in wing loading and adaptations to urban and agricultural areas. My results suggest that for nearly all bat species sampled, an absence of wetlands in the surrounding landscape may enhance the 
value of created wetlands regardless of size. Wetland characteristics such as $\mathrm{pH}$, age, and size did not influence activity or predict species presence. My results suggest that future mitigation decisions should consider land uses and habitat types surrounding a potential location of a compensatory mitigation wetland. Additionally, wetlands of all sizes, even small wetlands usually not protected under current regulations, can be important for bat species in the region. Because of the association of bats with wetlands, relative ease of acoustical monitoring, mobility, and longevity, bats may be good candidates as mammalian indicators for wetland function.

JOURNAL OF WILDLIFE MANAGEMENT 00(0): 000-000:2009 Key Words: acoustical monitoring, bats, mid-Atlantic, mitigation, Ohio, Pennsylvania, Upper Ohio River Valley, wetlands

\section{INTRODUCTION}

Knowledge of foraging requirements of bats is limited and results in uncertainty when making decisions on watershed management (Arnett 2003, Brooks and Ford 2005). For most bat species, flight activity is concentrated over riparian and wetland habitats (Grindal et al. 1999, Zimmerman and Glanz 2000, Francl et al. 2004, Owen et al. 2004, Brooks and Ford 2005). Because prey abundance is a critical factor in determining foraging patterns of bats (Barclay 1985, Gordon and Serfass 1989, Jung et al. 1999, Menzel et al. 2005), and many insect species depend on water for some part of their life cycle (Imes 1992), wetlands provide an important foraging habitat for many bat species. In the contiguous United States, $47 \%$ of wetlands have been lost since the $1780 \mathrm{~s}$, with the highest losses found in the intensively farmed Midwest; Ohio alone has lost over 
90\% of its pre-settlement wetlands (Dahl 1990). Some wetlands receive federal

protection under the Clean Water Act (CWA) of 1972 and subsequent 1977 amendments (Mitsch and Gosselink 2000). The U.S. Army Corps of Engineers (USACE) and the Environmental Protection Agency (EPA) regulate impacts to wetlands via Section 404 permits that are required to fill, drain, or degrade a wetland. Wetlands are delineated following a three-part examination of hydrology, soil, and vegetation (Cowardin et al. 1979, NRC 1995, Dahl 2006). Interpretation of a jurisdictional wetland under the CWA has changed since its inception. In 2001, a U.S. Supreme Court ruling altered Section 404 permitting to no longer protect isolated wetlands (Bedford and Godwin 2003), which are wetlands not directly connected to navigable waters, leaving states responsible for determining regulatory requirements of these wetlands (Osmond et al. 1995).

In 2006, interpretation of "significant nexus" was challenged in two court cases, Rapanos et al. v. United States and Carabell v. United States, when permits were denied for wetlands connected to navigable waters by drainage ditches (USACE/EPA 2008a). Revised guidance released in 2008 attempted to clarify the concept of relevant reach and adjacent wetlands that would be protected under the CWA (USACE/EPA 2008b). Waters not protected include those that do not flow at least three months, swales or small washes, and ditches (USACE/EPA 2008b).

The "no net loss" goal, introduced in 1988 by the Conservation Foundation and adopted as policy in 1990 (CEQ 2006), was instrumental in requiring that wetland loss be avoided or minimized before compensatory mitigation is undertaken (Mitsch and Gosselink 2000). Mitigation requires that jurisdictional wetlands lost to development must be compensated for by creating or restoring wetlands, or by protecting existing 
wetlands elsewhere. Wetland restoration is the process of returning a disturbed or altered wetland to a previously existing condition; wetland creation is the anthropogenic process of converting upland into wetland (NRC 1992). Mitigation is designed to offset the loss of specific wetland functions and its associated values, including habitat, within the watershed (NRC 2001).

If a wetland meets the jurisdictional definition for protection, it must also meet a size requirement of at least 0.13 ha before avoidance, minimization, or compensatory mitigation is required by the ACE (Snodgrass et al. 2000). Sites greater than 0.13 ha but less than 4.1 ha ( $<10$ acres) are usually granted a permit for disturbance, pending mitigation requirements (National Wetlands Policy 26). This leaves small isolated wetlands without protection (Osmond et al 1995). Between 1998 and 2004, 85\% of freshwater wetland losses were less than 2.0 ha (5.0 acres) in size, with $52 \%$ of those wetlands less than 0.4 ha (1.0 acre) (Dahl 2006). Urban and rural development was responsible for $61 \%$ of wetland losses (Dahl 2006). Agricultural drainage also caused the conversion of $75 \%$ of 33,751 ha ( 83,400 acres) of wetlands to upland; most of the drained wetlands were an average size of 1.6 ha (4.0 acres). Cumulative wetland losses across the United States were likely higher than reported due to additional, unaccounted loss of small isolated wetlands (Gladwin and Roelle 1992, Race and Fonseca 1996).

The deficit between successful mitigations and losses of non-jurisdictional wetlands is partially offset by voluntary wetland construction on public and private lands. In 2004, the U.S. President expanded the "no net loss" policy to increase the quantity and quality of wetlands annually through protection of high-quality wetlands and creation of new wetlands (CEQ 2006). Compensatory mitigation wetlands do not count towards 
created wetland acreage because it is a replacement for destroyed wetlands, and should theoretically compensate one for one. Federal programs that encourage private landowners to voluntary construct or restore wetlands include the Wetlands Reserve Program, Partners for Fish and Wildlife, Conservation Reserve Program, and Conservation Reserve Enhancement Program (CEQ 2006, O’Neal et al. 2008).

Between 1998 and 2004, wetland gains exceeded losses for the first time in history, with a net gain of 77,630 ha (191,750 acres); however, freshwater ponds accounted for the net gain with an increase of 281,500 ha (700,000 acres) (Dahl 2006). At the same time, freshwater emergent marshes decreased by 57,720 ha (142,570 acres). As the types of wetlands being lost or replaced changes from historical conditions, there also is a shift in wetland functions on the landscape (Mitsch and Gosselink 1993, NRC 1995, Brinson and Rheinhardt 1996). As wetlands are replaced with open ponds, functions such as improved water quality, plant communities, and habitat for wildlife are altered or lost (Magee et al. 1999, Mitsch and Gosselink 2000, CEQ 2006, Dahl 2006). Compensatory mitigation wetlands in theory must meet compliance to achieve regulatory certification. Ecosystem functions for wetland standards include hydrology, biogeochemistry, plant community, animal community, species diversity, and habitat (Brinson et al. 1994, NRC 2001). The most common and simple monitoring method is plant cover, which is often a poor indicator of function (Reinartz and Warne 1993, Mitsch and Wilson 1996). Reference wetlands often have greater plant richness and cover than compensatory wetlands. Moreover, physical similarities alone do not guarantee functional equality (Campbell et al. 2002). In reality, functional replacement is rarely achieved (Race 1985, Erwin 1991, NRC 1992, Brinsen and Reinhardt 1996). Placement 
of the wetland within the landscape is critical to long-term success, and sites surrounded by urban areas may be particularly vulnerable to hydrologic failure (Kentula et al. 2004, Kettlewell 2008).

The function of wildlife value is rarely measured because it is often considered more time consuming and costly than a quick and easy measure of percent surface water or plant cover (Mitsch and Wilson 1996, NRC 2001). Several studies have focused on avian (Hickman 1994, van Rees-Siewert and Dinsmore 1996, Melvin and Webb 1998, Davis et al. 2008, O’Neal et al 2008) and amphibian species composition (Funk and Dunlap 1999, Monello and Wright 1999, Lehtinen 2001) to assess wetland function (i.e. species diversity). Other studies have investigated invertebrate communities in constructed verses reference wetlands (Streever et al. 1996, Balcombe 2005b). Although numerous studies have examined bat use of natural wetlands and riparian areas, few have examined bat use of created wetlands. In South Carolina, Menzel et al. (2005a) reported bat activity increased almost immediately after Carolina bays were restored, as compared to reference wetlands. In Kentucky, constructed woodland ponds were used by bats during multiple seasons (Huie 2002).

All bat species in Pennsylvania and Ohio bats are known to use open or forested wetlands (Kirkland and Serfass 1989). Even species that day-roost in upland habitats routinely forage over wetland and riparian areas (Barbour and Davis 1969, van Zyll de Jong 1985, Merritt 1987, Jones and Rayner 1988). Furthermore, wetlands of all sizes represent valuable foraging habitat for many bat species (Francl 2008). Although 33 of Pennsylvania's 63 native mammals (53\%) derive benefit from wetlands, few studies have examined mammalian use of constructed wetlands. Bats as a taxonomic group are more 
closely associated with wetlands than most other mammals (Merritt 1987). Therefore, bats may serve as a practical mammalian indicator of habitat function due to their dependence on wetlands, ease of monitoring through acoustical technology, and their ubiquitous distribution across the landscape.

Given the increase in compensatory mitigation wetlands and voluntarily constructed wetlands, my study was a novel opportunity to investigate wetland design specifications and landscape placement relative to bats. My objective was to examine richness and relative activity of bats using created and natural wetlands and to determine the influence of wetland characteristics on bat presence and foraging. I modeled individual bat species presence and relative activity to wetland design parameters, landscape characteristics, and wetland origin. I then evaluated the models in an information theoretic framework to elucidate factors useful in decision-making for compensatory and voluntary wetland construction design.

\section{STUDY AREA}

I sampled wetlands for bat use in the Upper Ohio Valley region in western Pennsylvania and eastern Ohio. My study sites were located in Allegheny, Beaver, Center, Fayette, Greene, Washington, and Westmoreland counties in Pennsylvania, and Ashtabula, Carroll, Columbiana, Harrison, Jefferson, Trumbull, and Tuscarawas counties in Ohio (Fig. 2-1). All sites were located in the Central Hardwood region, either within the mixed mesophytic region of the Allegheny Plateau or Ohio Hills, or the beech (Fagus grandifloria)-maple (Acer sp.) forest region (Braun 1950, Hicks 1998). The geomorphology of the northern Ohio sites are maturely dissected glaciated plateaus, with the remainder of the sites in western Pennsylvania and eastern Ohio occupying a 
maturely dissected plateau (Bailey 1994, Hicks 1998). Elevation ranged from $198 \mathrm{~m}$ to 412 m (Bailey 1994, Hicks 1998).

In 2004 , mean temperature in northeast Ohio for June-August was $19.2^{\circ} \mathrm{C}(66.5$ $\left.{ }^{\circ} \mathrm{F}\right)$, with a departure from normal of $-2.9^{\circ} \mathrm{C}\left(-1.6^{\circ} \mathrm{F}\right)$, while during 2005 , the average was $21.9^{\circ} \mathrm{C}\left(71.5^{\circ} \mathrm{F}\right)$, with a departure from normal of $6.3^{\circ} \mathrm{C}\left(3.5^{\circ} \mathrm{F}\right)$. Precipitation for the area during 2004 was $9.9 \mathrm{~cm}$ (3.9 inches), with a $0.28 \mathrm{~cm}(0.11 \mathrm{inch})$ departure from normal, and in 2005 , it was $8.31 \mathrm{~cm}$ ( 3.27 inches) with a $-1.27 \mathrm{~cm}$ ( -0.5 inches) departure. In southwestern Pennsylvania, during June-August 2004, the mean temperature was $20.7^{\circ} \mathrm{C}$ $\left(69.2^{\circ} \mathrm{F}\right)$, departure of $-2.7^{\circ} \mathrm{C}\left(-1.5^{\circ} \mathrm{F}\right)$, and in 2005 , it was $23.1^{\circ} \mathrm{C}\left(73.5^{\circ} \mathrm{F}\right)$, departure of $5.0^{\circ} \mathrm{C}\left(2.8^{\circ} \mathrm{F}\right)$. Mean precipitation for southwest Pennsylvania during the same time was $42.67 \mathrm{~cm}$ (16.8 inches) in 2004, with a departure of $4.57 \mathrm{~cm}$ (1.8 inches), while in 2005, it was $9.65 \mathrm{~cm}$ ( 3.8 inches) with a departure of $-0.05 \mathrm{~cm}(-0.02$ inches) (NOAA 2005).

Of the 79 wetlands I sampled in 2004-2005, 30 were located in western Pennsylvania, and 49 in northeastern Ohio. Created wetlands ( $n=48)$ had approximately $50 \%$ palustrine open water with at least $25 \%$ palustrine emergent, based on the classification of Cowardin et al. (1979). I chose all wetlands for similar characteristics, approximately $50-75 \%$ open water and $25-50 \%$ emergent vegetation. Selected wetlands were constructed for various reasons including mitigation, waterfowl hunting, wildlife value, and other private use. Only a limited number of natural wetlands were available in the region and therefore I did not attempt to pair natural and created wetlands that were similar in characteristics and in close proximity for comparison. The natural wetlands $(n=31)$ were palustrine persistent emergent marshes dominated by cattail (Typha spp) with $<25 \%$ open water during summer. 


\section{METHODS}

\section{Site Selection}

In 2004-2005, I sampled 79 isolated, emergent and open-water wetlands in western Pennsylvania (n=30) and eastern Ohio $(n=49)$ (Fig. 2.1). I characterized wetlands by size (SIZE), age (AGE), pH (PH), presence of standing water (WET), and created versus natural origin (ORG) (Tables 2-1, 2-3).

I determined size of wetland from landowner information and maps, and treated it as a continuous variable. Age categories reflected anticipated successional changes as constructed wetlands matured, and were classified as categorical variables (Table 2-2). Initially following construction, wetlands are usually sparse in vegetation as plantings mature and/or the seed bank germinates. Wetlands can be classified as young when $<10$ years of age (Campbell et al. 2002). But regulatory agencies usually cease monitoring requirements by year five, which assumes the wetland is essentially established (Zedler 1996, Snodgrass et al. 2000). The $<5$-year age class accounts for the sparse vegetation common at this stage. As herbaceous succession continues between 5-20 years, vegetation becomes increasingly established. By year 20, a wetland may exhibit woody succession, thereby decreasing open water and altering other key characteristics such as plant communities (Mitsch and Gosselink 2000). Wetlands $>20$ years of age are uncommon due to the historical lack of regulation. The Clean Water Act of 1977 used Section 404 permits to require wetland mitigation in certain instances but mitigation was much less common than in recent times. The six wetlands $>20$ years old were created on public land for waterfowl hunting in the 1970s. Created wetlands in our study had approximately $50 \%$ palustrine open water and at least $25 \%$ palustrine emergent according to the classification of Cowardin et al. (1979). Wetlands were constructed for various 
purposes including compensatory mitigation, waterfowl management, wildlife value, and recreation. Ages of natural wetlands in my study were unknown. Because natural wetlands were certainly older than the created wetlands, they were categorized in the $>20$-year age class (Table 2-2). Most of the natural wetlands were palustrine persistent emergent marshes dominated by cattail (Typha spp.) with $<25 \%$ open water during summer.

As an indicator of insect abundance, I measured $\mathrm{pH}$ of standing water at wetland sites with a $\mathrm{pH}$ meter. I created two categories to examine impact on prey base, circumneutral or dry (0), and not neutral (1) (Table 2-3). Circumneutral waters are able to sustain insect populations that serve as prey, whereas both acidic and alkaline waters host less insect diversity or abundance (Parsons 1968, Roback and Richardson 1969, Warner 1971, Kimmel 1983, Earle and Callaghan 1998). Wetlands that did not have sufficient surface water to test $\mathrm{pH}$ were categorized into circumneutral ( 0 ) because there was no effect of water chemistry on insect abundance. Because some wetlands had visible, standing water, and several did not, a category (WET) was created to account for the presence of water on bat activity.

\section{Landscape Analysis}

I acquired Geographic Positioning System (GPS) locations for all wetland sites and imported the data into ArcView 3.3 as a centrally located point. I measured distance (DIST) to nearest state route or interstate highway from the site's central point. Bats may use gravel or paved roads for commuting and navigation (Limpens et al. 1989, Zimmerman and Glanz 2000), though few studies have examined intra- or interstate highways. I calculated edge density (ED) as the amount of edge within the landscape using ArcView Tools as a measure of fragmentation. This is biologically relevant 
because bats are known to travel and forage along ecotones (Menzel 2003, Gerht and Chelsvig 2004, Ford et al. 2005). I calculated a Shannon's diversity index for each site as a second measure of fragmentation. This measure of relative patch diversity increases as the proportional distribution of patch types increases (McGaril and Marks 1994).

I classified land cover types using National Land Cover Data (NLCD) grids (U.S. Geological Survey 1999a,b). I then reclassified each land cover class in the raster grid (30 m cell size) as urban (URB), barren (BAR), agricultural (AG), forest (FOR), open water (WAT), or wetland (WETL) based on the NLCD classifications and biological relevance to bat species (Gerht and Chelsvig 2004) (Table 2-3). I examined the surrounding land use when sampling each wetland, and land uses did not change significantly according to these broad reclassifications. Urban areas included commercial, industrial, and residential uses. Species such as the big brown bat and little brown bat in particular are known to exploit insect concentrations in lighted, urban areas (Furlonger et al. 1997, Rogers et al. 2006), and roost within buildings (Barbour and Davis 1969, Agosta and Morton 2003). However, urban development can threaten the hydrologic integrity of created wetlands (Kentula et al. 2004, Kettlewell 2008). Barren areas included bare ground, quarries, strip mines, and gravel pits; such habitats void of vegetation are considered poor bat habitat (Tibbels and Kurta 2003, Menzel et al. 2005). Agriculture included pasture, hay, and crops. Big brown bats in particular are known to forage selectively on agricultural crop pests such as scarab beetles (Coleoptera) and green stink bugs (Hemiptera) (Whitaker 1995, Agosta and Morton 2003). Forest type at all study sites was primarily deciduous or mixed deciduous forest, and reclassified as a single forest category. Most bats roost within forests and forage in openings and along 
edges, depending on species (Grindal and Brigham 1999, Francl et al. 2004b, Owen et al. 2004). The Water land cover class included all open water, whereas the Wetland class represented areas of woody or emergent herbaceous wetland in the landscape. Proximity to area of open water is important for bats (Brooks and Ford 2005, Schirmacher et al. 2007).

Because most bat species present have relatively limited home range extents $(<1,000$ meters in radius) during summer months (Adam et al. 1994, Krishon et al. 1997, Carter et al. 1999, Owen et al. 2003), I created a buffer of 1,000 meters around each central point. I used the Patch Analyst (Grid) extension to determine mean patch size for each reclassified land use category (Rempel and Carr 2003).

\section{Acoustical Sampling}

To determine species presence, I used active acoustical sampling with an Anabat II detection system linked to a storage ZCAIM (Titley Electronics, Ballina, Australia). I conducted acoustical sampling from 1 June through 15 September, 2004 and 2005, to reduce intraseasonal variation for the region (Whitaker and Hamilton 1998, Ford et al. 2005). Of the 79 sites, I sampled 9 sites only in 2004, 53 sites once in 2004 and once in 2005, and 17 sites in 2005 alone. I was unable to return to the 9 sites sampled only in 2004 due to safety or access issues which were not evident before sampling. I discovered the 17 sites sampled in 2005 after the sampling season ended. Sites sampled once in 2004 were sampled again once in 2005 to record additional species that may not have been observed previously. This repeated measure was staggered among months and time of night to account for possible differences in occurrence throughout the season and nocturnal activity patterns. 
I actively recorded bat calls for 20 minutes per wetland with a slow sweeping motion to capture call sequences (O'Farrell et al. 1999, Johnson et al. 2002, Ford et al. 2006). I oriented the detector over open water with no obstructions to reduce the impact of clutter on calls (Obrist 1995). Johnson et al. (2002) compared passive versus active monitoring and concluded that active was superior in obtaining higher quality calls of longer sequences, and that it better assessed richness by capturing less distinct calls of Myotids. I sampled between 2100-0100 hours when bat activity is greatest (Kunz 1974, Kunz and Brock 1975, Thomas and West 1991, Jones et al. 1996, Zielinski and Gellman 1999, Seidman and Zabel 2001) and only on nights with no rain or high winds, and when temperatures exceeded $15.6^{\circ} \mathrm{C}\left(60^{\circ} \mathrm{F}\right)$ (Ford et al. 2005).

I analyzed calls to determine species presence using Anabat $6.2 \mathrm{~d}$ software and Anabat V Zero-Crossing Analysis Interface Module (Corben 1999), and examined calls in the software program Analook $4.7 \mathrm{j}$ (Corben 1999) using filter parameters similar to Britzke and Murray (2000). I identified only those call sequences containing at least 3 quality pulses (Johnson et al. 2002). Each series of feeding buzzes was counted and pooled across species as a relative index of foraging in order to examine general bat use of wetlands versus commuting. Myotid calls were identified based on frequency and slope characteristics (O’Farrell 1997, Britzke and Murray 2000). If a call was deemed questionable, the record was discarded. To aid identification, I examined bat calls using a qualitative, dichotomous key, developed using a reference library created by M. Menzel and J. Johnson (unpublished data) that included over 8,000 calls. I identified all calls to reduce bias and increase consistency (O'Farrell et al. 1999). Two other researchers experienced in bat call identification randomly verified identification accuracy. 


\section{Statistical Analysis}

Using site and landscape variables (Table 2-3), I developed a series of a priori models to predict the influence of wetland conditions on bat presence and use. Models were based on personal knowledge and literature of bat natural history and development of wetlands (Whitaker and Hamilton 1998, Lehtinen and Galatowitsch 2001, Balcombe 2005a,b, Ford et al. 2005, Menzel et al. 2005, Ford et al. 2006). Wetland size, areas of land use, edge density, Shannon's diversity index, and distance to highway were continuous independent variables (Table 2-3). Wetland site characteristics such as origin, age, $\mathrm{pH}$, and standing water were categorical variables. Prior to fitting models, I examined possible correlation among variables using Pearson's product-moment correlation (Proc Corr; SAS Institute 1990). If variables were highly correlated (>0.6), I retained the most biologically meaningful variable to bats.

I developed six models, including a global model containing all variables and subset models (Table 2-4). I used these model sets to examine the response variables of bat presence, relative activity, and foraging. My Wetland model contained physical characteristics of wetlands associated with compensatory mitigation engineering and monitoring, such as size, age, and origin. My Origin model examined wetland origin and presence of water to determine influence of created wetlands on bats. The Landscape model included only landscape-level variables such as edge density, open water in landscape, forest, and surrounding wetlands. These habitat variables related foraging habits and wing morphology (Francl et al. 2004b, Owen et al. 2004, Menzel et al. 2005b). The Open model examined landscape types with open habitats such as urban and agricultural areas, as well as distance to nearest major highway. The Combo model was a 
combination of landscape-level variables and size of wetland that may influence bat use. Several studies have suggested bat activity may be influenced by wetland or pond size in relation to surrounding habitat (Zimmerman and Glanz 2000, Downs and Racey 2006, Francl 2008, Brooks 2009).

I used logistic regression analyses with repeated measures (Proc Genmod; SAS Institute, Inc. 1990) to develop predictive models of bat species presence. Because I could not assume the bat population was adequately measured, I estimated intensity of use rather than abundance. I developed a relative index of activity by examining only sites where bats were present $(n=70)$, and counted recorded calls by individuals of each species. I also measured response variables of total species richness. Of sites with bats present, 46 of the wetlands were sampled in 2004-2005, 9 sampled only in 2004, and 15 sampled only in 2005. I also examined a relative index of foraging activity at each wetland by pooling feeding buzzes among all species to examine foraging use versus commuting. I developed multiple regression models with a negative binomial distribution to account for unequal sampling and used the repeated measures statement within a generalized linear model format (Proc Genmod; SAS Institute, Inc. 1990). The negative binomial distribution is useful for count data from biological populations with heterogeneity, does not assume normality, and may reduce bias (White and Bennetts 1996, Boyce et al. 2001). I assessed fit of the global model using the scaled Pearson's chi-square statistic and associated cumulative P-value.

I used an information-theoretic approach to select models based on Akaike's Information Criteria adjusted for small sample size, $\mathrm{AIC}_{c}, \mathrm{AIC}_{c}$ differences $\left(\Delta_{i}\right)$, and Akaike weights $\left(\omega_{i}\right)$ (Burnham and Anderson 2002). Candidate models were ranked 
according to their $\mathrm{AIC}_{c}$ values, with the smallest value approximating the best model. Models with $\mathrm{AIC}_{\mathrm{c}}$ differences $\leq 2$ were considered supported. I calculated Akaike weights $\left(\omega_{i}\right)$ to estimate weight of evidence that a given model was the best model in the candidate set (Burnham and Anderson 2002). To estimate correct classification rates of global logistic models, I used a jack-knife procedure with a probability threshold of 0.50 . To validate multiple regression models post hoc, I created a model of all variables in competing models $\left(\mathrm{AIC}_{c}<2\right)$, and then calculated percent residuals above and below the confidence intervals to better understand if expected values under- or overestimated observed values.

\section{RESULTS}

In summer 2004, I sampled 62 wetlands and recorded 1,064 identifiable search phase passes and 660 feeding buzzes at 52 sites. I identified little brown bats (Myotis lucifugus) ( $n=385)$ at 26 sites, eastern pipistrelles (Pipistrellus subflavus) $(n=69)$ at 16 sites, big brown bats (Eptesicus fuscus) $(n=248)$ at 31 sites, hoary bats (Lasiurus cinereus $)(n=197)$ at 26 sites, eastern red bats $($ L. borealis $)(n=130)$ at 27 sites, unidentified Myotids $(n=18)$ at 6 sites, and northern myotis $(M$. septentrionalis $)(n=17)$ at 7 sites. There were 10 sites with no recorded calls. An additional 152 calls were of insufficient call duration or quality to identify.

In summer 2005, I sampled 70 wetlands, and recorded 718 identifiable calls and 254 feeding buzzes at 54 sites. I identified little brown bats $(n=321)$ at 40 sites, northern myotis $(n=6)$ at 3 sites, eastern pipistrelles $(n=144)$ at 19 sites, big brown bats $(n=137)$ at 30 sites, hoary bats $(n=43)$ at 16 sites, eastern red bats $(n=61)$ at 21 sites, and unidentified Myotis $(n=6)$ at 3 sites. Sixteen sites had no recorded calls, and an 
additional 40 calls were of insufficient call duration or quality to identify. I excluded northern myotis from my analyses because of small sample sizes in both years. Northern myotis are often undersampled acoustically due to their short call duration and gleaning habits (Denzinger et al. 2003). Because northern myotis are more commonly associated with closed-canopy forests and small, first-order streams (McKenzie and Rolfe 1986, Denzinger et al. 2003, Owen et al. 2003), their presence was unlikely in the open wetlands sampled in my study.

Shannon's Diversity Index (SDI) and Edge Density were the only variable pair to exceed $(\mathrm{r}=0.63)$ the correlation threshold of 0.60 (Proc Corr; SAS Institute 1990). I removed SDI from the global model because Edge Density is simpler to interpret when considering management implications.

Model selection and subsequent analysis of estimates suggested that specific landscape characteristics influenced all bat species presence and relative activity (Tables 2-5, 2-6). Only the eastern pipistrelle was influenced by both the Landscape model $\left(w_{\mathrm{AICc}}=0.62\right)$ and the Origin model $\left(w_{\mathrm{AIC} c}=0.24\right)($ correct classification $=51 \%)$. The Landscape model was best supported for presence of little brown bat $\left(w_{\mathrm{AIC} C}=0.85\right.$, correct classification $=61 \%)$ and hoary bat $\left(w_{\mathrm{AICc}}=0.82\right.$, correct classification $\left.=48 \%\right)$. Wetlands influenced all three of these species, but only little brown bats were more likely present at sites surrounded by more wetlands in the landscape. Conversely, hoary and eastern pipistrelles were influenced by sites that had fewer wetlands in the 1,000 meter buffer surrounding the site.

The Open model was best model for predicting presence of big brown bats $\left(w_{\text {AICC }}=0.88\right.$, correct classification $\left.=51 \%\right)$; the big brown bat was the only species to 
demonstrate a positive relation to barren areas. The eastern red bat was influenced by agriculture and urban areas in the landscape, as evidenced by the competing models of Combo $\left(w_{\mathrm{AIC} c}=0.58\right)$, and Open $\left(w_{\mathrm{AIC}}=0.24\right)($ correct classification $=56 \%)$.

For species richness, the Open $\left(w_{\mathrm{AIC}}=0.48\right)$ and Combo models $\left(w_{\mathrm{AIC}}=0.26\right)$ were competing models. Richness was greatest with diversity of land uses, particularly agriculture, edge, and distance to nearest road. Although estimates were weak, goodnessof-fit for most global models were adequate to strong $(\mathrm{P}>0.60)$. Residuals were $31 \%$ within confidence intervals, $38 \%$ below, and $30 \%$ above, demonstrating approximately one-third of observed values fell within the predicted value when tested post hoc. Competing models for foraging (as indicated by total feeding buzzes) include Combo $\left(w_{\mathrm{AICC}}=0.53\right)$ and Landscape $\left(w_{\mathrm{AIC} C}=0.34\right)$. The Combo model over-predicted foraging, with percent residuals $31 \%$ within, $56 \%$ below, and $20 \%$ above confidence intervals. The pooling of feeding buzzes across species likely minimized any differentiation among niches and habitat preferences of species, and contributed to the poor model fit and weak estimates.

Relative activity of all species was influenced by landscape, except for the eastern pipistrelle, which was influenced by natural wetlands (Origin model, $w_{\mathrm{AICC}}=0.53$ ). For relative index of activity of the little brown bat (Table 2-6), the Combo $\left(w_{\text {AIC }}=0.40\right)$, Origin $\left(w_{\mathrm{AIC}}=0.28\right)$, and Open models $\left(w_{\mathrm{AICC}}=0.22\right)$ were competing. Percent residuals were $27 \%$ within, $56 \%$ below, and $17 \%$ above confidence intervals. Little brown bats were more active at study wetlands located within a landscape with less agriculture and urban areas, which may be due to less foraging opportunities in the landscape. 
Conversely, an increase in agriculture positively influenced eastern red bats, with the Combo model $\left(w_{\mathrm{AICc}}=0.84\right)$ as the only supported model.

For big brown bats, competing models included Open $\left(w_{\mathrm{AIC}}=0.37\right)$, Origin $\left(w_{\mathrm{AICc}}=0.34\right)$, and Landscape $\left(w_{\mathrm{AICc}}=0.15\right)$, with higher activity in landscapes with more urban areas and less wetlands. Competing models for the hoary bat were the Landscape model $\left(w_{\mathrm{AIC} c}=0.49\right)$ and Combo $\left(w_{\mathrm{AIC} c}=0.39\right)$, with an increase in wetlands within the landscape negatively impacting activity.

\section{DISCUSSION}

To maximize benefit of created wetlands for bats, site placement within the landscape may be the most influential factor examined. The influence of each landscape type varied slightly among species given differences in their wing loading and echolocation characteristics, adaptation to urban and agricultural areas, and selected habitats among bats. But the area of forest, surrounding open water and wetlands, and edge influenced every species, which is consistent with previous findings in the eastern region of the United States (Owen et al. 2004, Ford et al. 2005, Schirmacher et al. 2007).

\section{Species Richness, Presence, and Foraging}

Bat species richness was highest over larger wetlands in areas with more forest

and edge, and that were closer to roads. Although the latter was unexpected, roads create more edge for commuting bats (Limpens et al. 1989, Zimmerman and Glanz 2000). Likewise, even though many bat species are considered less common within urban areas (Gerht and Chelsvig 2004), richness was greater. Individual bat species differ in their response to urban areas, with open-adapted species often positively impacted (Furlonger et al 1987, Gaisler et al 1998, Gerht and Chelsvig 2004). Big brown bats were most 
influenced by barren and urban areas surrounding the wetland site. This landscape likely attracts generalist species that can use the available open and edge habitat, whether roads or urban interfaces, while those that select intact forest still find sufficient core habitat. In-kind mitigation near an urban development site may still provide some benefit to bats, despite threats to hydrology and long-term site protection (Kentula et al. 2004, Kettlewell 2008).

Bat foraging activity was greatest over larger wetlands within forested landscapes, with less agriculture and less edge. Edge density likely provides additional and accessible sources of prey, thereby reducing concentrated feeding over the wetland. Pooling feeding buzzes across species may have eliminated potentially important differences among species in determining presence. For instance, agriculture influenced some bat species differently. Clutter-adapted species such as little brown bats were negatively impacted by intensive agricultural areas, whereas eastern red bats were positively influenced. Because of their morphological adaptations, species such as hoary bats could be expected to access prey more efficiently in open, clutterless areas (Aldridge 1987, Menzel et al. 2005b), and big brown bats prey heavily on several crop pests (Agosta and Morton 2003). However, this impact varies widely based on intensity and type of farming, and can reduce available prey (Walsh and Harrison 1996, Fenton 1997, Gerht and Chelsvig 2004). Further examination of agricultural areas, and in particular prey availability, could elucidate a potentially complex relation. However, constructing wetlands in agricultural settings may not be optimal for bat foraging compared to other habitats. 
Larger wetlands provide suitable habitat for open-adapted species, and an increase in water could be expected to positively impact insect abundance (Wallace and Merritt 1999), hence increasing foraging activity. Bat activity over all pools in forests of Massachusetts was high, with greatest activity and bat diversity over large ponds (Brooks and Ford 2005, Brooks 2009). In the northern Great Lakes region, both small and large wetlands were shown to have value to bats (Francl 2008), and in the southwest, even small water-filled ruts are important in landscapes lacking water (Wilhide et al. 1998). Although I specifically measured foraging as the number of feeding buzzes pooled across species, bats can also be expected to drink from wetlands as well, and this subtle difference would not be captured in the study. Within the supported models, size of the wetland had weak explanatory power. Therefore, created wetlands, regardless of size, may serve as important foraging areas, especially when located optimally within the landscape.

\section{Bat Activity}

Because bats are volant and highly mobile, the importance of a wetland's context within the surrounding landscape exerted influence on activity, with species-specific differences. Although size of wetland was a variable in competing models for some species, its contribution was low, perhaps because wetlands of all sizes may provide value to bats (Wilhide et al. 1998, Francl 2008, Brooks 2009).

Little brown bats were more likely present at wetlands that were surrounded in a landscape with higher wetland acreage, and showed higher levels of activity as agriculture declined. Because little brown bats are generalists that may forage on crop pests, less agriculture in the landscape could enhance the importance of the wetland for 
foraging (Walsh and Harrison 1996, Fenton 1997, Gerht and Chelsvig 2004), or

conversely agriculture could reduce insect diversity and hence potential prey. In contrast, agriculture positively impacted the presence and activity of red bats, which demonstrate broad habitat associations due to body size and diet (Carter et al. 2004, Menzel et al. 2005b, Schmiracher et al. 2007). Red bats are often detected feeding and traveling along forest edge (Kunz 1973, Hart et al. 1993, Harvey et al. 1999), especially when combined with water sources such as open and wooded streams, or ponds and lakes (Davis and Mumford 1962, Schirmacher et al. 2007). Therefore, the ecotones created by a wetland near agriculture and forest may be particularly attractive to red bats.

Big brown bats were associated with increased open areas such as barren and urban landscapes. Species with high wing-loading use such open, less cluttered environs effectively (Menzel et al. 2005b), and are associated with more open forests and riparian habitats (Ford et al. 2005, Ford et al. 2006, Schirmacher et al. 2007). They are also most associated with highly urban areas, adapted to buildings, attics, and development (Gerht and Chelsvig 2004, Loeb et al. 2009). Parks in urban settings may be important refugia for certain bats, particularly big brown bats in the mid-Atlantic region (Johnson et al. 2008, Loeb et al. 2009). Wetlands within urban areas could be similar to, or located within, park-like conditions, and could be serving as important foraging or drinking areas where conditions are suitable for their presence.

Hoary bats forage in large, intact forests in the Northeast (Veillueux et al. 2009), and conversely, in the Midwest, in open and edge habitats (Barclay 1995, Sparks et al. 2005). However, the amount of wetlands in the landscape surrounding the study wetland was the strongest, negative influence on both presence and activity. When there is less 
water within the landscape, created wetlands may become particularly important. There also was a weak, unexpected association with smaller wetlands. This did not conform to expectations because hoary bats are known to frequent habitats with expanses of open water (Hart et al. 1993), although large intact forests could be expected to have less open water. The importance of various sized wetlands for bats was also demonstrated by Francl (2008) in woodland seasonal ponds. Historical losses and limited studies of small wetlands within the landscape may have underestimated their importance for protection. Of all freshwater wetland losses, $85 \%$ were wetlands less than 2.0 ha (5.0 acres) in size; $52 \%$ were wetlands less than 1.0 acre ( 0.4 ha) (Dahl 2006). Only wetlands over 0.13 ha receive protections under the CWA by the ACOE. Therefore, the 43 sampled wetlands in this size category would not qualify for protection or mitigation under Section 404. This is a concern given the importance of wetlands of all sizes to bat species.

\section{Wetland Origin}

Pipistrelles were more likely present at study wetlands within forested landscapes that had less water and wetlands. However, where pipistrelles were present, relative activity was positively associated with natural wetlands. Previous research has shown that certain guilds of bird species are negatively impacted by created wetlands (SnellRood and Cristoll 2003). Suppressed vegetation growth and delayed development impact avian richness, whereas natural wetlands are often structurally more complex (Mitchell and Lancia 1990, Kellison and Young 1997). The complexity of natural wetlands may likewise influence pipistrelles because they are clutter-adapted. Prey associated with wetland succession might also be affected; for example, a low shrub layer provides refuge and results in higher insect densities (Tibbles and Kurta 2003, Francl 2008). 
Natural wetlands may enhance foraging for species adapted to a cluttered environment, as the habitat surrounding the natural wetland may be less disturbed than a constructed wetland. The most important influence upon pipistrelles could be a preference for small canopy gaps within immediate surrounding canopy and structure (Francl 2008).

In contrast, little brown and big brown bat activity was positively influenced by created wetlands. However, the model was not the best supported in any given set, and the presence of standing water had a negative influence on big brown bats but was positive on little brown bats. This was expected as most bat species appear to use created wetlands regardless of plant community development or age (Menzel 2005a, Menzel et al. 2006). Bats were found to quickly use restored Carolina Bay wetlands, suggesting that restoration can have an immediate impact (Menzel et al. 2006). Created wetlands often have less clutter than the surrounding landscape or natural wetlands, and this moderate clutter is ideal for many generalist species (Menzel et al. 2005a). Created wetlands also did not have to be large to be utilized by bats in this study. Origin may not impact bat use as much as avian guilds because most bat species in the study area prefer less structurally complex areas or are generalists, compared to the avian guilds that are sometimes used as wetland indicators. In addition, many bird species nest within and forage differently within wetlands, and therefore require different plant structure.

\section{Influence of wetland characteristics}

Abiotic wetland design characteristics such as size, age, origin, $\mathrm{pH}$, and presence of standing water received little support for influencing bat activity. This lack of influence is somewhat unexpected because vegetation succession should be more advanced in older wetlands, and therefore either negatively or positively impact bat 
foraging given a species preference for more or less cluttered environments. However, wetland development takes over 20 years for woody succession to occur (Mitsch and Wilson 1996), so many of the wetlands may not be mature enough to adequately examine this factor. In addition, the tendency of mitigation wetlands to be designed as deep water or ponds to meet ACE requirements (USACE 1997, Kettlewell 2008) could minimize succession and this impact. Likewise, $\mathrm{pH}$ can impact insect abundance and hence prey base (Barclay 1985, Gordon and Serfass 1989, Jung et al. 1999). My results suggest that the location of a wetland within the landscape is more important for use by bat species than physical design alone. Unfortunately, most compensatory mitigation wetlands stress physical design parameters and do not consider landscape location as an important criteria (Mitsch and Gosselink 2000, NRC 2001). If certain landscape-level features are limited, such as edge, open water, or other wetlands, created wetlands could provide needed habitat for bat species. Such factors may be more important than origin, age, or even size.

\section{MANAGEMENT IMPLICATIONS}

Constructed and natural wetlands positively influence bat presence, relative activity, and foraging, particularly if the landscape is lacking other water sources and edge density. These wetlands also do not have to be large to provide benefit. Small isolated wetlands lack protection (Osmond et al 1995), are key for regional biodiversity (Semlitsch and Bodie 1998), and should therefore be considered important for bat conservation. Because bats benefit from wetlands of all sizes, bats should be considered in design criteria and assessment of created wetlands. 


\section{LITERATURE CITED}

Adam, M. D., M. J. Lacki, T. G. Barnes. 1994. Foraging areas and habitat use of the Virginia big-eared bat in Kentucky. Journal of Wildlife Management 58:462469.

Agosta. S.J. and D. Morton. 2003. Diet of the big brown bat, Eptesicus fuscus, from Pennsylvania and Western Maryland. Northeastern Naturalist 10(1): 89-104.

Aldridge, H.D. and I.L. Rautenach. 1987. Morphology, echolocation, and resource partitioning in insectivorous bats. Journal of Animal Ecology 56: 763-778.

Altringham, J.D. 1996. Bats: biology and behavior. Oxford University Press, London, United Kingdom.

Ashley, Michael C., J.A. Robinson, L.W. Oring, G.A. Vinyard. 2000.

Dipteran standing stock biomass and effects of aquatic bird predation at a constructed wetland. Wetlands 20: 84-90.

Bailey, R.G. 1994. Ecoregions of the United States (map). Rev. USDA Forest Service, Washington D.C.

Balcombe, Collin K., J.T. Anderson, R.H. Fortney, J.S. Rentch, W.N. Grafton, and W.S. Kordek. 2005a. A comparison of plant communities in mitigation and reference wetlands in the mid-Appalachians. Wetlands 25:1: 130-142.

Balcombe, Collin K., J.T. Anderson, R.H. Fortney, J.S. Rentch, W.N. Grafton, and W.S. Kordek. 2005b. Aquatic macroinvertebrate assemblages in mitigated and natural wetlands. Hydrobiologia 541: 165-188. 
Barbour, R.W. and W.H. Davis. 1969. Bats of America. University of Kentucky Press, Lexington. $286 \mathrm{pp}$.

Barclay, R.M.R. 1985. Long verses short-range foraging strategies of hoary (Lasiuris cinereus) and silver-haired (Lasionycteris noctivagens) bats and the consequences for prey selection. Canadian Journal of Zoology 63: 2507-2515.

Bedford, B.L. and K. Godwin. 2003. Fens of the United States: distribution, characteristics, and scientific connection versus legal isolation. Wetlands. 23:608-629.

Boyce, M. S., MacKenzie, D.I., Manly, B. F. J., Haroldson, M. A. and Moody, D. 2001. Negative binomial models for abundance estimation of multiple closed populations. Journal of Wildlife Management 65(3): 498-509.

Braun, E.L. 1950. Deciduous forests of Eastern North America. Blakiston Co., Philadelphia, PA. 596 pp.

Brigham, R.M. and Fenton, M.B. 1991. Convergence in foraging strategies by two morphologically and phylogenetically distinct nocturnal aerial insectivores. Journal of Zoology 223: 475-489.

Britzke, E.R., and K.L. Murray. 2000. A quantitative method for selection of identifiable search-phase calls using the Anabat system. Bat Research News 41:33-36.

Brooks, R.T., and W. M. Ford. 2005. Bat Activity in a Forest Landscape of Central Massachusetts. Northeastern Naturalist 12(4):447-462. 
Brooks, R.T. 2009. Habitat-associated and temporal patterns of bat activity in a diverse forest landscape of southern New England, USA. Biodiversity Conservation 18:529-545.

Bunnell, J.F. and R.A. Zamplella. 1999. Acid water anuran pond communities along a regional forest to agro-urban ecotone. Copeia 1999:614-627.

Burnham, K.P. and D.R. Anderson. 1998. Model selection and inference: a practical information-theoretic approach. Springer-Verlag, New York, NY, USA.

Burnham, K.P. and D.R. Anderson. 2002. Model selection and multi-model inference: a practical information-theoretic approach. Second edition. Springer-Verlag, New York, USA.

Campbell, Deborah A, C.A. Cole, R.P. Brooks. 2002. A comparison of created and natural wetlands in Pennsylvania, USA. Wetlands Ecology and Management Vol. 10, Issue 1, pp: $41-49$.

Carter, T. C., M. A. Menzel, B. R. Chapman, and K. V. Miller. 1999. Summer foraging and roosting behavior of an eastern pipistrelle (Pipistrellus subflavus). Bat Research News 40:5-6.

Cohn, Jeffrey P. 2008. White-nose syndrome threatens bats. BioScience 58(11) p 1098. doi 10.1641/B581116.

Corben, C. 1999. Anabat. Version 6.2d. Computer software. IBM.

Council on Environment Quality. 2005. Conserving America's Wetlands: Implementing the President's Goal. Executive Office of the President, Washington, D.C. 
Council on Environment Quality. 2006. Conserving America's Wetlands 2006: Two years of progress implementing the President's goal. Executive Office of the President, Washington, D.C.

Crome, F.H.J, and Richards, G.C. 1988. Bats and gaps: microchiropteran community structure in a Queensland rain forest. Ecology. 69:1960-1969.

Cryan, P.M., M.A. Bogan, and G.M. Yanega. 2001. Roosting habits of four bat species in the Black Hills of South Dakota. Acta Chiropterologica 3:43-52.

Dahl, T.E. 1990 . Wetlands losses in the United States, 1780 's to 1980 's. United States Department of the Interior, Fish and Wildlife Service, Washington, D.C., U.S.A.

Dahl, T.E. 2000. Status and trends of wetlands in conterminous United States 1986 to 1997. U.S. Department of the Interior, Fish and Wildlife Service, Washington, D.C.

Dahl, T.E. 2006. Status and trends of wetlands in the conterminous United States 1998 to 2004. U.S. Department of the Interior; Fish and Wildlife Service, Washington, D.C. $112 \mathrm{pp}$.

Davis, W.H., and R.E. Mumford. 1962. Ecological notes on the bat Pipistrellus subflavis. American Midland Naturalist 68:394-398.

Downs, Nick C., and Paul A. Racey. 2006. The use by bats of habitat features in mixed farmland in Scotland. Acta Chiropterologica 8(1): 169-185.

Earle, Jane, and T. Callaghan. Impacts of acid mine drainage on aquatic life, water uses, and man-made structures. Chapter 4, in Brady, Smith, and Schueck, editors. Coal mine drainage prediction and pollution prevention in Pennsylvania. The 
Pennsylvania Department of Environmental Protection. http://www.dep.state.pa.us/dep/deputate/minres/districts/cmdp/main.htm.

Erwin, K. 1991. An evaluation of wetland mitigation in the South Florida Water Management District, West Palm Beach, Florida, USA

Fenton, M.B. 1969. Summer activity of Myotis lucifugus at hibernacula in Ontario and Quebec. Canadian Journal of Zoology 47: 597-602.

Fenton, M.B. 1990. The foraging behaviour and ecology of animal-eating bats. Canadian Journal of Zoology 68:411-422.

Fenton, M.B. 1997. Science and the conservation of bats. Journal of Mammalogy 78:1-14.

Fenton, M. B. 2000. Choosing the "correct" bat detector. Acta chiropterologica 2:215-224.

Fenton, M.B. 2003. Science and the conservation of bats: where to next? Wildlife Society Bulletin 31:45-61.

Fenton, M.B. and G.P. Bell. 1979. Echolocation and feeding behaviour in four species of Myotis (Chiroptera). Canadian Journal of Zoology, 57:1271-1277.

Fenton, M.B. and G.P. Bell. 1981. Recognition of species of insectivorous bats by their echolocation calls. Journal of Mammalogy, 62:233-243.

Fenton, M.B., H.G. Merriam, and G.L. Holroyd. 1983. Bats of Kootenay, Glacier, and Mount Revelstoke national parks in Canada: identification by echolocation calls, distribution, and biology. Canadian Journal of Zoology, 61:2503-2508.

Fenton, M. B.; N. G. H. Boyle; T. M. Harrison; D. J. Oxley. 1977. Activity 
Patterns, Habitat Use, and Prey Selection by Some African Insectivorous Bats. Biotropica, Vol. 9, No. 2. pp. 73-85.

Flaquer, C., X. Puig-Montserrat, U. Goiti, F. Vidal, A. Curco, and D. Russo. 2009. Habitat selection in Nathusius' pipistrelle (Pipistrellus nathusii): the importance of wetlands. Acta Chiropterologica 11(1): 149-155.

Ford, W.M., M.A. Menzel, J.L. Rodrigue, J.M. Menzel and J.B. Johnson. 2005. Relating bat species presence to simple habitat measures in a central Appalachian forest. Biological Conservation 126: 528-539.

Ford, W.M., J.M. Menzel, M.A. Menzel, J.W. Edwards, and J.C. Kilgo. 2006. Bat activity patterns across habitat scales in the upper coastal plain of South Carolina. Journal of Wildlife Management (in press).

Francl, K. E., W. M. Ford, and S. B. Castleberry. 2004a. Bat activity in central Appalachian wetlands. Research Note. Newton Square, PA: U.S. Department of Agriculture, Forest Service, Northeastern Research Station.

Francl, K. E., W. M. Ford, and S. B. Castleberry. 2004b. Characterization of high elevation central Appalachian wetlands. Res. Pap. NE-725. Newton Square, PA: U.S. Department of Agriculture, Forest Service, Northeastern Research Station. 26p.

Francl, K. E. 2008. Summer bat activity at woodland seasonal pools in the northern Great Lakes region. Wetlands 28:1, pp 117-124.

Funk, W.C. and W.W. Dunlap. 1999. Colonization of high-elevation lakes by longtoed salamanders (Ambystoma macrodactylum) after extinction of introduced trout populations. Canadian Journal of Zoology 77: 1759-1767. 
Furlonger, C.L, H.J. Dewar, M.B. Fenton. 1987. Habitat use by foraging insectivorous bats. Can J Zool 65:284-288.

Gannon, W.L., R.E. Sherwin, and S. Haymond. 2003. On the importance of articulating assumptions when conducting acoustic studies of habitat use by bats. Wildlife Society Bulletin 31(1):45-61.

Gerht, Stanley, and Chelsvig, James E. 2003. Bat activity in an urban landscape: patterns at the landscape and microhabitat scale. Ecological Applications. 13(4): 939-950.

Gerht, Stanley, and Chelsvig, James E. 2004. Species specific patterns of bat activity in an urban landscape. Ecological Applications. 14(2): 625-635.

Gibbs, J.P. 1993. Importance of small wetlands for the persistence of local populations of wetland-associated animals. Wetlands. 13:25-31.

Gladwin, D., and J. Roelle. 1992. Nationwide permits: case studies highlight concerns. National Wetlands Newsletter 14(2):7-9.

Grindal, S.D., Morissette J.L., and Brigham, R.M. 1999. Concentration of bat activity in riparian habitats over an elevational gradient. Canadian Journal of Zoology 77: 972-977.

Hart, J.A., G.L. Kirkland, Jr., and S.C. Grossman. 1993. Relative abundance and habitat use by tree bats, Lasiurus spp., in southern Pennsylvania. Canadian Field Naturalist 107: 208-212.

Harvey, M.J., J.S. Altenbach, and T.L. Best. 1999. Bats of the United States. Arkansas Game and Fish Commission, Little Rock, Arkansas, USA. 
Hayes, J.P. and P. Hounihan. 1994. Field use of the Anabat II bat detector system to monitor bat activity. Bat Research News 35:1-3.

Hayes, J.P. 2000. Assumptions and practical considerations in the design and interpretation of echolocation-monitoring studies. Acta Chiropterologica. 2:225236.

Hickey, MBC,L Acharya,S Pennington. 1996. Resource partitioning by two species of vespertilionid bats (Lasiurus cinereus and Lasiurus borealis) feeding around street lights. Journal of Mammalogy 77:325-334.

Hickman, S. 1994. Improvement of habitat quality for nesting and migrating birds at the Des Plaines River wetlands demonstration project. Ecological Engineering 3:485494.

Hicks, Ray R. 1998. Ecology and management of central hardwood forests. John Wiley and Sons. New York, New York. 412pp.

Imes, R. 1992. The Practical Entomologist. Simon and Schuster, Inc. New York, NY, USA.

Johnson, J.B., M.A. Menzel, J.W. Edwards, and W.M. Ford. 2002. A comparison of 2 acoustical bat survey techniques. Wildlife Society Bulletin 30(3): 931-936.

Johnson, J.B., M.A. Menzel, J.W. Edwards, W.M. Ford and J.T. Petty. 2006. Spatial and predictive foraging models for gray bats in northwest Georgia. Acta Chiropterlogica (in review).

Johnson, J., J.E. Gates, and W.M. Ford. 2008. Distribution and activity of bats at local and landscape scales within a rural-urban gradient. Urban Ecosystems 11:227242. 
Jones, C., W. J. McShea, M. J. Conroy, and T. H. Kunz. 1996. Capturing mammals. Pp. 115-155 in Measuring and monitoring biological diversity: standard methods for mammals (D.E. Wilson, F. R. Cole, J. D. Nichols, R. Rudran, and M.S. Foster, eds.). Smithsonian Institution Press, Washington, D.C.

Jones, G. and J.M.V. Rayner. 1988. Flight performance, foraging tactics, and echolocation in free-living Daubenton's bats Myotis daubentoni (Chiroptera: Vespertilionidae). J. Zoo., London. 215:113-132.

Jung, T.S., I.D. Thompson, R.D. Titman and A.P. Applejohn. 1999. Habitat selection by forest bats in relation to mixed-wood stand types and structure in central Ontario. Journal of Wildlife Management 63:1306-1319.

Kalcounis-Rueppell MC, VH Payne, SR Huff, AL Boyko. 2007. Effects of wastewater treatment plant effluent on bat foraging ecology in an urban stream system. Biological Conservation 138:120-130.

Kentula, M.E., S.E. Gwin, S.M. Pierson. 2004. Tracking changes in wetlands with urbanization: sixteen years of experience in Portland, Oregon, USA. Wetlands 24:734-43.

Kettlewell, C. 2005. An inventory of Ohio wetland compensatory mitigation, Part 2. Ohio Environmental Protection Agency, Division of Surface Water, Wetland Ecology Group, Final Report to U.S. EPA Grant No. CD97576201-0, Columbus, $\mathrm{OH}$.

Kettlewell, C., V. Bouchard, D. Porej, M. Michaccion, J.J. Mack, D. White, and L. Fay. 2008. An assessment of wetland impacts and compensatory mitigation in the Cuyahoga River watershed, Ohio, USA. Wetlands 28(1): 57-67. 
Kimmel, W.G., 1983. The impact of acid mine drainage on the stream ecosystem. In: Pennsylvania Coal: Resources, Technology and Utilization, (S. K. Majumdar and W. W. Miller, eds.), The Pa. Acad. Sci. Publ., pp. 424-437.

Krishon, D. M., M. A. Menzel, T. C. Carter, and J. Laerm. 1997. Notes on the home range of four species of Vespertilionid bats (Chiroptera) on Sapelo Island, Georgia. Georgia Journal of Science. 55:215-223.

Krusic, R.A., M. Yamasaki, C.D.Neefus, and P.J. Perkins. 1996. Bat habitat use in White Mountain National Forest. Journal of Wildlife Management 60:625-631.

Kunz, T. H. 1973. Resource utilization: temporal and spatial components of bat activity in central Iowa. Journal of Mammalogy 54:14-32.

Kunz, T. H. 1974. Feeding ecology of a temperate insectivorous bat (Myotis velifer). Ecology 55:693-711.

Kunz, T. H, and C. E. Brock. 1975. A comparison of mistnet and ultrasonic detectors for monitoring flight activity of bats. Journal of Mammalogy 56:907-911.

Kunz, T.H. and M.B. Fenton. 2003. Ecology of bats. University of Chicago Press, Chicago, Illinois, U.S.A.

Lehtinen, Richard M. and S. M. Galatowitsch. 2001. Colonization of restored wetlands by amphibians in Minnesota. American Midland Naturalist 145 (2): 388-396.

Limpens, H. J. G. A., W. Helmer, A. Van Winden, and K. Mostert. 1989. Bats (Chiroptera) and linear landscape elements: a review of our present knowledge of the importance of linear land- scape elements to bats. Lutra 32:1-20. 
Loeb, S.C., C.J. Post, and S.T. Hall. 2009. Relationship between urbanization and bat community structure in national parks of the southeastern U.S. Urban Ecosystem 12: $197-214$.

Lowry, Dennis J. 1990. Restoration and creation of palustrine wetlands associated with riverine systems of the glaciated northeast. In Wetland Creation and Restoration: the status of the science. Editors Jon A. Kusler and Mary E. Kentula. Island Press.

MacSwiney, M. C., B.B. Cime, F.M. Clarke, P.A. Racey. 2009. Insectivorous bat activity at cenotes in the Yucatan Peninsula, Mexico. Acta Chiropterologica 11(1): 139-147.

McGarigal and B.J. Marks. 1994. Fragstats: Spatial pattern analysis program for quantifying landscape structure. Reference manual. For. Sci. Dep. Oregon State University. Corvallis Oregon 62 p.+ Append.

McGarigal, K., S. A. Cushman, M. C. Neel, and E. Ene. 2002. FRAGSTATS: Spatial Pattern Analysis Program for Categorical Maps. Computer software program produced by the authors at the University of Massachusetts, Amherst. Accessed 12/05 at www.umass.edu/landeco/research/fragstats/fragstats.html.

Menzel, J.M., M.A. Menzel, J.C. Kilgo, W.M. Ford and J.W. Edwards. 2005a. Bat response to Carolina bays and wetland restoration in the southeastern U.S. Coastal Plain. Wetlands Journal 25:542-550.

Menzel, J.M., M.A. Menzel, J.C. Kilgo, W.M. Ford, J.W. Edwards and G.F. McCracken. 2005b. Effect of habitat and foraging height on bat activity in the Coastal Plain of South Carolina. Journal of Wildlife Management 69:235-245. 
Menzel, Michael A, Menzel, J.M, Kilgo, J.C., (and others). 2003. Bats of the Savannah River site and vicinity. Gen. Tech. Rep. SRS-68. Asheville, N.C., US Department of Agriculture, Forest Service, Southern Research Station. 69p.

Merritt, J.F. 1987. Guide to the mammals of Pennsylvania. University of Pittsburgh Press, Pittsburgh PA. 408 pp.

Mitsch, W.J., and J.G. Gosselink. 2000. Wetlands, Third edition. Wiley and Sons, New York, New York, 920pp.

Mitsch, William H. and R.F. Wilson. 1996. Improving the success of wetland creation and restoration with know-how, time, and self-design. Ecological Applications 6(1): 77-83.

Monello, R.J. and R.G. Wright. 1999. Amphibian habitat preferences among artificial ponds in the Palouse region of northern Idaho. Journal of Herpetology 33:298303.

National Oceanic Atmospheric Administration. 2005a. National Environmental Satellite, Data, and Information Services (NESDIS). Accessed 12/2005 at www.ncdc.noaa.giv/oa/climate/research.

National Oceanic Atmospheric Administration. 2005b. An Introduction and User's Guide to Wetland Restoration, Creation, and Enhancement. Interagency Workgroup on Wetland Restoration. Washington, D.C., U.S.A

National Research Council. 1992. Restoration of aquatic ecosystems: science, technology, and public policy. National Academy Press, Washington D.C., USA. 
National Research Council. 1995. Wetlands: Characteristics and boundaries. Committee on Characterization of Wetlands, Water Science and Technology Board. National Academy Press, Washington, D.C. 268 p.

National Research Council. 2001. Compensating for Wetland Losses under the Clean Water Act. Washington DC: National Academy Press.

National Wetlands Policy Forum. 1988. Protecting America's wetlands: an action agenda. The Conservation Foundation, Washington, D.C., U.S.A.

Obrist, M.K. 1995. Flexible bat echolocation: the influence of individual, habitat, and conspecifics on sonar signal design. Behavioral Ecology and Sociobiology. $36: 207-216$.

O'Farrell, M.J. 1997. Use of echolocation calls for the identification of free-flying bats. Transactions of the Western Section of the Wildlife Society, 33:1-8.

O’Farrell, Michael J. and W. L. Gannon. 1999. A comparison of acoustic versus capture techniques for the inventory of bats. Journal of Mammalogy, 80(1): 24-30.

O’Neal, B. J. 2003. Wetland habitat in the Conservation Reserve Enhancement Program: monitoring and predicting use by migrant and resident waterbirds. Thesis, University of Illinois Urbana-Champaign, Champaign, USA.

O’Neal, B. J., and E. J. Heske. 2007. Characterization of wetlands in the Conservation Reserve Enhancement Program in Illinois. Transactions of the Illinois State Academy of Science, Springfield, USA.

O’Neal, B.J., E.J. Heske, and J.D. Stafford. 2008. Waterbird response to wetlands restored through the conservation reserve enhancement program. Journal of Wildlife Management 72(3): 654-664. 
O’Shea, T.J., Bogan, M.A., and L.E. Ellison. 2003. Monitoring trends in bat populations of the United States and territories: status of the science and recommendations for the future. Wildlife Society Bulletin 31(1): 16-19.

Osmond, D.L., D.E. Line, J.A. Gale, et al. 1995. WATERSHEDSS: water, soil, and hydroenvironmental decision support system. Available at http://h2osparc.wq.ncsu.edu.

Owen, S. F., M. A. Menzel, W. M. Ford, B. R. Chapman, K. V. Miller, J. W. Edwards, P. B. Wood. 2003. Home-range size and habitat used by the northern myotis (Myotis septentrionalis). The American Midland Naturalist 150:352-359.

Owen, S.F., M.A. Menzel, J.W. Edwards, W.M. Ford, J.M. Menzel, B.R. Chapman, P.B. Wood and K.V. Miller. 2004. Bat activity in harvested and intact forest stands in the Allegheny Mountains. Northern Journal of Applied Forestry 21:154-159.

Parsons, J.D., 1968. The effects of acid strip-mine effluents on the ecology of a stream. Arch. Hydrobiol., v. 65, pp. 25-50.

Peters, N.E. and J.E. Bonelli, 1982. Chemical composition of bulk precipitation in the north-central and northeastern United States, December 1980 through February 1981. U.S. Geological Survey Circular 874, 63 p.

Porej, D. 2003. An inventory of Ohio wetland compensatory mitigation, Part 1. Ohio Environmental Protection Agency, Division of Surface Water, Wetland Ecology Group, Final Report to U.S. EPA Grant No. CD97576201-0, Columbus, OH.

Race, M.S. and M.S. Fonseca. 1996. Fixing compensatory mitigation: what will it take? Ecological Applications 6(1): 94-101. 
Ramsar Convention Secretariat. 2007. Wise use of wetlands: A conceptual framework for the wise use of wetlands. Ramsar handbooks for the wise use of wetlands. $3^{\text {rd }}$ Edition. Ramsar Convention Secretariat, Gland, Volume 1, 26 pp.

Reddy E, F.B. Fenton FB. 2003. Exploiting vulnerable prey: moths and red bats (Lasiurus borealis; Vespertilionidae). Can J Zool 81:1553-1560. doi:10.1139/z03-146.

Rempel, R.S. and A. P. Carr. 2003. Patch Analyst extension for ArcView: version 3. http://flash.lakeheadu.ca/ rrempel/patch/index.html

Roback, S.S. and J.W. Richardson, 1969. The effects of acid mine drainage on aquatic insects. Proc. Acad. Nat. Sci. Phil., v. 121, pp. 81-107.

Royall, R. M. 1997. Statistical evidence: a likelihood paradigm. Chapman \& Hall, London, United Kingdom.

SAS Institute. 1990. SAS User's Guide. Version 6.02. SAS Institute, Cary, North Carolina, USA.

Schirmacher, M.R., S.B. Castleberry, W.M. Ford, and K.V. Miller. 2007. Habitat associations of bats in south-central West Virginia. Proceedings Annual Conference Southeast Association Fish and Wildlife Agencies 61:46-52.

Simmons, J.A. and R.A. Stein. 1980. Acoustic imaging in bat sonar: echolocation signals and the evolution of echolocation. Journal of Comparative Physiology $135: 61-84$

Seidman, V.M. and C.J. Zabel. 2001. Bat activity along intermittent streams in northwestern California. Journal of Mammalogy 82:738-747. 
Semlitsch, R.D. and J.R. Bodie. 1998. Are small isolated wetlands expendable? Conservation Biology 12: 1129-1133.

Snell-Rood, E.C. and D. A. Cristol. 2003. Avian communities of created and natural wetlands: bottomland forests in Virginia. The Condor. 105:303-315.

Snodgrass, Joel W., M.J. Komoroski, A. L. Bryan Jr., and J. Burger. 2000. Relationships among isolated wetland size, hydroperiod, and amphibian species richness: implications for wetland regulations. Conservation Biology, 14(2): 414-419.

Sparks, D.W., C.M. Ritzi, and B.I. Everson. 2005. Nocturnal behavior and roosting ecology of a juvenile Lasiuris cinereus near Indianapolis, Indiana. Proceedings of the Indiana Academy of Science 114-70-72.

Streever, W.J., K.M. Portier, and T.L. Crisman. 1996. A comparison of dipterans from ten created and ten natural wetlands. Wetlands 16: 416-428.

Thomas, D. W. and S. D. West. 1989. Sampling methods for bats. United States Forest Service General Technical Report PNW-243:1-20.

Tibbels, A.E. and A. Kurta. 2003. Bat activity Is low in thinning and unthinned stands of red pine. Canadian Journal of Forest Research 33:2436-2442.

USACE/EPA (U.S. Army Corps of Engineers and U.S. Environmental Protection Agency). 2008a. Clean Water Act Jurisdiction following the U.S. Supreme Court's decision in Rapanos v. United States and Carabell v. United States. December 2, 2008.

USACE/EPA (U.S. Army Corps of Engineers and U.S. Environmental Protection Agency). 2008b. Response to comments "Clean Water Act Jurisdiction following 
the U.S. Supreme Court's decision in Rapanos v. United States and Carabell v. United States guidance" December 2, 2008.

U.S. Geological Survey. 1999a. Ohio Land Cover Data Set. Sioux Falls, SD USA. http://edcwww.cr.usgs.gov/programs/lccp/nationallandcover.html.

U.S. Geological Survey. 1999b. Pennsylvania Land Cover Data Set. Sioux Falls, SD USA. http://edcwww.cr.usgs.gov/programs/lccp/nationallandcover.html.

Van Zyll de Jong, C.G. 1985. Bats. National Museums of Canada. Ottawa. 212 pp. Veillux, J.P., P.R. Moosman Jr., D.S. Reynolds, K.E. LaGory, and L.J. Walston, Jr. 2009. Observations of summer roosting and foraging behavior of a hoary bat (Lasiurus cinereus) in southern New Hampshire. Northeastern Naturalist Notes $16 / 1$.

Wallace, J.R. and R.W. Merritt. 1999. Influence of microclimate, food, and predation on Anopheles quadrimaculatus (Diptera: Cuclicidae) growth and development rates, survivorship, and adult size in a Michigan pond. Environmental Entomology 28:223-239.

Warner, R.W., 1971. Distribution of biota in a stream polluted by acid mine-drainage. Ohio J. Sci., v. 71, pp. 202-215.

Whitaker, John O. 2004. Prey selection in a temperate zone insectivorous bat community. Journal of Mammalogy 85: 460-469.

Whitaker, John O, and W.J. Hamilton. 1998. Mammals of the Eastern United States. Cornell University Press, Ithaca, NY, 583 pp. .

White, Gary C., Robert E. Bennetts. 1996. Analysis of frequency count data using the negative binomial distribution. Ecology 77(8): 2549-2557. 
Wilhide, J.D., M.J. Harvey, V.R. McDaniel, and V.E. Hoffman. 1998. Highland pond utilization by bats in the Ozark National Forest, Arkansas. Journal of the Arkansas Academy of Science 52:110-112.

Zedler, Joy B. 1996. Ecological issues in wetland mitigation: an introduction to the forum. Ecological Applications, 6(1): 33-37.

Zielinski, William J.; Gellman, Steven T. 1999. Bat Use of Remnant Old-Growth Redwood Stands. Conservation Biology, Vol. 13, No. 1, pp. 160-167.

Zimmerman, G.S., and W.E. Glanz. 2000. Habitat use by bats in eastern Maine. Journal of Wildlife Management 64:1032-1040. 
Table 2-1. Characteristics of sampled wetlands $(n=79)$ in western Pennsylvania and eastern Ohio.

\begin{tabular}{lcccc}
\hline & & \multicolumn{2}{l}{ Constructed } & wetlands age \\
\cline { 3 - 5 } Size & Natural & $<5$ years & $5-20$ years & $>20$ years \\
\hline Small $(<4$ ha $)$ & 18 & 11 & 11 & 3 \\
Medium $(4-8$ ha $)$ & 9 & 4 & 11 & 1 \\
Large $(8-40$ ha $)$ & 5 & 2 & 4 & 1 \\
Extra large $(>40$ ha) & 0 & 0 & 1 & 1 \\
Totals & 33 & 17 & 27 & 6 \\
\hline
\end{tabular}


Table 2-2. Age categories of sampled wetlands $(n=79)$ in western Pennsylvania and eastern Ohio.

\begin{tabular}{llc}
\hline Description & Category & $\mathrm{n}$ \\
\hline Created, $<5$ years & 0 & 16 \\
Created, 6-20 years & 1 & 28 \\
Created or Natural, 21 years and & 2 & 35 \\
older & & \\
\end{tabular}


Table 2-3. Biotic and abiotic parameters included in negative binomial and logistic regression models explaining wetland and landscape relationship of bat presence and relative abundance in sampled wetlands in western Pennsylvania and eastern Ohio.

\begin{tabular}{|c|c|c|c|}
\hline Variable & $\begin{array}{l}\text { Abbreviatio } \\
\mathrm{n}\end{array}$ & $\begin{array}{l}\text { Variable } \\
\text { Type }\end{array}$ & Additional Description \\
\hline Origin & ORG & Categorical & Natural (0) vs Constructed (1) origin of wetland \\
\hline Size & SIZE & Continuous & Size of wetland (hectares) \\
\hline Age of & $\mathrm{AGE}$ & Categorical & Age categories of wetland in years (table 2-2) \\
\hline wetland & & & \\
\hline $\mathrm{pH}$ & PH & Categorical & Neutral pH (7.0-7.9) or dry (0), Not neutral (1) \\
\hline Wet & WET & Categorical & Presence of standing water in wetland (1), dry $(0)$ \\
\hline Distance & DIST & Continuous & Distance to nearest major highway as determined \\
\hline to highway & & & with spatial analysis (meters) \\
\hline Edge & ED & Continuous & amount of edge relative to the landscape within \\
\hline density & & & 1,000 meter buffer of wetland \\
\hline Water & WAT & Continuous & Area of open water in surrounding landscape \\
\hline Urban & URB & Continuous & $\begin{array}{l}\text { Area of residential, commercial, industrial, or } \\
\text { transportation use }\end{array}$ \\
\hline Barren & BAR & Continuous & $\begin{array}{l}\text { Area of bare ground, quarries, strip mines, gravel } \\
\text { pits }\end{array}$ \\
\hline Forest & FOR & Continuous & $\begin{array}{l}\text { Area of deciduous, evergreen, and mixed upland } \\
\text { forest }\end{array}$ \\
\hline Agriculture & $\mathrm{AG}$ & Continuous & Area of pasture, hay, row crops, small grains \\
\hline Wetland & WETL & Continuous & Area of woody or herbaceous wetland in landscape \\
\hline
\end{tabular}


Table 2-4. Model set explaining wetland and landscape relationship of bat presence and relative abundance in sampled wetlands in western Pennsylvania and eastern Ohio.

\begin{tabular}{ll}
\hline Model & \multicolumn{2}{c}{ Parameters $^{\text {a }}$} \\
\hline Global & AG AGE BAR DIST ED FOR ORG PH SIZE URB WAT WET \\
& WETL \\
Wetland & AGE ORG PH SIZE WET \\
Origin & ORG WET \\
Landscape & ED FOR WAT WETL \\
Open & AG BAR DIST URB \\
Combo & AG ED FOR SIZE \\
\hline
\end{tabular}

${ }^{a}$ Abbreviations correspond to model parameters in Table 2-3. 
Table 2-5. Logistic regression analysis and model selection using Akaike Information Criteria (AICc) difference with correction for small sample sizes ( $\triangle$ AICc $)$ and model weight (wAICc) for wetland characteristics and presence/absence of each bat species at each wetland $(\mathrm{n}=79)$ in western Pennsylvania and eastern Ohio, June-August.

\begin{tabular}{lcccc} 
Model $^{\mathrm{a}}$ & $\mathrm{K}^{\mathrm{b}}$ & $\mathrm{AIC}_{c}$ & $\Delta \mathrm{AIC}_{c}$ & $w_{\mathrm{AIC} c}$ \\
\hline Little brown myotis & & & & \\
Landscape & 6 & 182.31 & 0.00 & 0.85 \\
Origin & 4 & 187.49 & 5.18 & 0.06 \\
Combo & 6 & 188.61 & 6.30 & 0.04 \\
Wetland & 8 & 188.75 & 6.44 & 0.03 \\
Open & 6 & 190.59 & 8.28 & 0.01 \\
Global & & & & 0.00 \\
Eastern pipistrelle & 16 & 203.04 & 20.74 & 0.00 \\
$\quad$ Landscape & & & & 0.02
\end{tabular}


Table 2-5. Continued.

\begin{tabular}{|c|c|c|c|c|}
\hline Model $^{\mathrm{a}}$ & $\mathrm{K}^{\mathrm{b}}$ & $\mathrm{AIC}_{c}$ & $\Delta \mathrm{AIC}_{c}$ & $w_{\mathrm{AICc}}$ \\
\hline Combo & 6 & 157.99 & 4.07 & 0.08 \\
\hline Wetland & 8 & 158.73 & 4.80 & 0.06 \\
\hline Open & 6 & 161.95 & 8.03 & 0.01 \\
\hline Global $^{\mathrm{d}}$ & 16 & 168.70 & 14.77 & 0.00 \\
\hline \multicolumn{5}{|l|}{ Big brown bat } \\
\hline Open & 6 & 180.58 & 0.00 & 0.89 \\
\hline Origin & 4 & 185.31 & 4.73 & 0.08 \\
\hline Combo & 6 & 188.65 & 8.06 & 0.02 \\
\hline Landscape & 6 & 189.86 & 9.28 & 0.01 \\
\hline Wetland & 8 & 192.29 & 11.71 & 0.00 \\
\hline Global $^{\mathrm{e}}$ & 16 & 192.11 & 11.53 & 0.00 \\
\hline \multicolumn{5}{|l|}{ Red bat } \\
\hline Combo & 6 & 176.38 & 0.00 & 0.58 \\
\hline
\end{tabular}


Table 2-5. Continued.

\begin{tabular}{|c|c|c|c|c|}
\hline Model $^{\mathrm{a}}$ & $\mathrm{K}^{\mathrm{b}}$ & $\mathrm{AIC}_{c}$ & $\Delta \mathrm{AIC}_{c}$ & $w_{\text {AIC }}$ \\
\hline Open & 6 & 178.13 & 1.75 & 0.24 \\
\hline Origin & 4 & 179.10 & 2.72 & 0.15 \\
\hline Landscape & 6 & 182.26 & 5.88 & 0.03 \\
\hline Wetland & 8 & 186.37 & 9.99 & 0.00 \\
\hline Global $^{\mathrm{f}}$ & 16 & 197.02 & 20.64 & 0.00 \\
\hline \multicolumn{5}{|l|}{ Hoary bat } \\
\hline Landscape & 6 & 164.62 & 0.00 & 0.82 \\
\hline Combo & 6 & 168.96 & 4.34 & 0.09 \\
\hline Origin & 4 & 169.89 & 5.27 & 0.06 \\
\hline Open & 6 & 171.10 & 7.20 & 0.02 \\
\hline Wetland & 8 & 176.68 & 12.06 & 0.00 \\
\hline Global $^{\mathrm{g}}$ & 16 & 178.42 & 13.80 & 0.00 \\
\hline
\end{tabular}

\footnotetext{
${ }^{a}$ Models are defined in Table 2-4.

${ }^{\mathrm{b}}$ Number of estimable parameters in approximating model.

${ }^{c}$ Scaled Pearson $\chi 2=128.32, P=0.76$
} 
${ }^{\mathrm{d}}$ Scaled Pearson $\chi 2=184.62, \mathrm{P}=0.99$

${ }^{\mathrm{e}}$ Scaled Pearson $\chi 2=123.75, \mathrm{P}=0.66$

${ }^{\mathrm{f}}$ Scaled Pearson $\chi 2=130.03, \mathrm{P}=0.79$

${ }^{\mathrm{g}}$ Scaled Pearson $\chi 2=136.29, \mathrm{P}=0.88$ 
Table 2-6. Negative binomial regression analysis and model selection using Akaike Information Criteria (AICc) difference with correction for small sample sizes ( $\triangle$ AICc ) and model weight (wAICc) for wetland characteristics and species richness and foraging activity recorded and number of recorded bats at each wetland $(n=79)$ in western Pennsylvania and eastern Ohio, June-August.

\begin{tabular}{lcccc} 
Model $^{\mathrm{a}}$ & $\mathrm{K}^{\mathrm{b}}$ & $\mathrm{AIC}_{c}$ & $\Delta \mathrm{AIC}_{c}$ & $w_{\mathrm{AIC} c}$ \\
\hline Species Richness & & & & \\
Open & 6 & 93.10 & 0.00 & 0.48 \\
Combo & 6 & 94.32 & 1.22 & 0.26 \\
Origin & 4 & 95.32 & 2.22 & 0.16 \\
Landscape & 6 & 96.32 & 3.22 & 0.10 \\
Wetland & 8 & 103.44 & 10.34 & 0.00 \\
Global & & & & 0.00 \\
Foraging Activity & 16 & 108.15 & 15.05 & \\
Combo & & & & 0.53 \\
Landscape & 6 & -3348.56 & 0.00 & 0.34
\end{tabular}


Table 2-6. Continued.

\begin{tabular}{|c|c|c|c|c|}
\hline Model $^{\mathrm{a}}$ & $\mathrm{K}^{\mathrm{b}}$ & $\mathrm{AIC}_{c}$ & $\Delta \mathrm{AIC}_{c}$ & $w_{\mathrm{AICc}}$ \\
\hline Open & 6 & -3344.71 & 3.85 & 0.08 \\
\hline Origin & 4 & -33473.82 & 4.74 & 0.05 \\
\hline Wetland & 8 & -3340.18 & 10.73 & 0.00 \\
\hline Global $^{\mathrm{d}}$ & 16 & -3333.63 & 25.19 & 0.00 \\
\hline \multicolumn{5}{|c|}{ Little brown myotis } \\
\hline Combo & 6 & -2772.17 & 0.00 & 0.40 \\
\hline Origin & 4 & -2771.47 & 0.69 & 0.28 \\
\hline Open & 6 & -2770.95 & 1.22 & 0.22 \\
\hline Landscape & 6 & -2769.09 & 3.07 & 0.09 \\
\hline Wetland & 8 & -2766.27 & 5.89 & 0.02 \\
\hline Global $^{\mathrm{e}}$ & 16 & -2750.49 & 21.68 & 0.00 \\
\hline \multicolumn{5}{|c|}{ Eastern pipistrelle } \\
\hline Origin & 4 & -489.19 & 0.00 & 0.53 \\
\hline
\end{tabular}


Table 2-6. Continued.

\begin{tabular}{|c|c|c|c|c|}
\hline Model $^{\mathrm{a}}$ & $\mathrm{K}^{\mathrm{b}}$ & $\mathrm{AIC}_{c}$ & $\Delta \mathrm{AIC}_{c}$ & $w_{\mathrm{AICC}}$ \\
\hline Wetland & 8 & -486.75 & 2.44 & 0.16 \\
\hline Combo & 6 & -486.49 & 2.70 & 0.14 \\
\hline Open & 6 & -485.83 & 3.36 & 0.10 \\
\hline Landscape & 6 & -485.49 & 3.70 & 0.08 \\
\hline Global $^{\mathrm{f}}$ & 16 & -470.19 & 19.00 & 0.00 \\
\hline \multicolumn{5}{|l|}{ Big brown bat } \\
\hline Open & 6 & -812.75 & 0.00 & 0.37 \\
\hline Origin & 4 & -812.62 & 0.13 & 0.34 \\
\hline Landscape & 6 & -810.91 & 1.84 & 0.15 \\
\hline Combo & 6 & -810.91 & 1.84 & 0.12 \\
\hline Wetland & 8 & -806.71 & 6.05 & 0.02 \\
\hline Global $^{\mathrm{g}}$ & 16 & -800.58 & 12.17 & 0.00 \\
\hline
\end{tabular}


Table 2-6. Continued.

\begin{tabular}{|c|c|c|c|c|}
\hline Model $^{\mathrm{a}}$ & $\mathrm{K}^{\mathrm{b}}$ & $\mathrm{AIC}_{c}$ & $\Delta \mathrm{AIC}_{c}$ & $w_{\mathrm{AICc}}$ \\
\hline Combo & 6 & -157.50 & 0.00 & 0.84 \\
\hline Origin & 4 & -153.42 & 4.08 & 0.11 \\
\hline Open & 6 & -151.17 & 6.33 & 0.04 \\
\hline Landscape & 6 & -147.66 & 9.83 & 0.01 \\
\hline Wetland & 8 & -148.29 & 9.21 & 0.01 \\
\hline Global $^{\mathrm{h}}$ & 16 & -141.05 & 16.45 & 0.00 \\
\hline \multicolumn{5}{|l|}{ Hoary bat } \\
\hline Landscape & 6 & -502.59 & 0.00 & 0.49 \\
\hline Combo & 6 & -502.15 & 0.44 & 0.39 \\
\hline Origin & 4 & -498.68 & 3.91 & 0.07 \\
\hline Open & 6 & -499.02 & 4.90 & 0.04 \\
\hline Wetland & 8 & -493.88 & 8.71 & 0.01 \\
\hline Global $^{\mathrm{i}}$ & 16 & -490.50 & 12.09 & 0.00 \\
\hline
\end{tabular}


a Abbreviations correspond to model parameters in Table 1. A "+" before a variable indicates a positive relation, while a "-" indicates a negative relation.

${ }^{\mathrm{b}}$ Number of estimable parameters in approximating model.

${ }^{c}$ Scaled Pearson $\chi 2=129.00, P=0.96$

${ }^{\mathrm{d}}$ Scaled Pearson $\chi 2=113.79, \mathrm{P}=0.80$

${ }^{\mathrm{e}}$ Scaled Pearson $\chi 2=127.66, \mathrm{P}=0.96$

${ }^{\mathrm{f}}$ Scaled Pearson $\chi 2=90.53, \mathrm{P}=0.22$

${ }^{\mathrm{g}}$ Scaled Pearson $\chi 2=92.40, \mathrm{P}=0.26$

${ }^{\mathrm{h}}$ Scaled Pearson $\chi 2=93.15, \mathrm{P}=0.28$

${ }^{\mathrm{i}}$ Scaled Pearson $\chi 2=105.87, \mathrm{P}=0.62$ 
Table 2-7. Variables included in best approximating candidate models selected using Akaike Information Criteria (AIC $)^{\text {within }}$ logistic regression analysis predicting bat presence at wetlands.

\begin{tabular}{|c|c|c|c|c|c|}
\hline Parameter & Estimate & $\mathrm{SE}$ & $\mathrm{Z}$ & $\operatorname{Pr}>|Z|$ & $95 \% \mathrm{CL}$ \\
\hline \multicolumn{6}{|l|}{ Little brown bat } \\
\hline \multicolumn{6}{|l|}{ Landscape $^{\mathrm{a}}$} \\
\hline Intercept & -0.01 & 1.03 & -0.01 & 0.10 & $-2.02-2.01$ \\
\hline ED & -0.00 & 0.01 & -0.36 & 0.72 & $-0.01-0.01$ \\
\hline FOREST & 0.00 & 0.01 & 0.00 & 0.99 & $-0.03-0.03$ \\
\hline WATER & 0.07 & 0.06 & 1.19 & 0.23 & $-0.04-0.18$ \\
\hline WETLAND & 0.33 & 0.20 & 1.68 & 0.09 & $-0.06-0.72$ \\
\hline \multicolumn{6}{|l|}{ Pipistrelle } \\
\hline \multicolumn{6}{|l|}{ Landscape $^{\mathrm{b}}$} \\
\hline Intercept & -1.97 & 1.17 & -1.68 & 0.09 & $-4.26-0.33$ \\
\hline ED & 0.01 & 0.01 & 1.07 & 0.29 & $-0.01-0.02$ \\
\hline FOREST & 0.01 & 0.01 & 0.98 & 0.33 & $-0.01-0.04$ \\
\hline WATER & -0.01 & 0.02 & -0.29 & 0.77 & $-0.04-0.03$ \\
\hline WETLAND & -0.70 & 0.38 & -1.86 & 0.06 & $-1.45-0.04$ \\
\hline \multicolumn{6}{|l|}{ Origin $^{c}$} \\
\hline Intercept & -2.17 & 0.78 & -2.78 & 0.01 & $-3.70--0.64$ \\
\hline ORG & 0.34 & 0.42 & 0.80 & 0.42 & $-0.49-1.17$ \\
\hline WET & 1.03 & 0.79 & 1.31 & 0.19 & $-0.51-2.57$ \\
\hline
\end{tabular}


Table 2-7. Continued.

\begin{tabular}{lccccc}
\hline Parameter & Estimate & SE & $Z$ & $\operatorname{Pr}>|Z|$ & $95 \%$ CL \\
\hline $\begin{array}{c}\text { Big brown bat } \\
\text { Open }{ }^{d}\end{array}$ & & & & & \\
Intercept & -0.47 & 0.38 & -1.24 & 0.22 & $-1.20-0.27$ \\
URBAN & -0.02 & 0.12 & -0.20 & 0.84 & $-0.26-0.21$ \\
AG & 0.07 & 0.05 & 1.35 & 0.18 & $-0.03-0.18$ \\
BARREN & 0.13 & 0.07 & 1.96 & 0.05 & $0.00-0.27$ \\
DIST & -0.00 & 0.00 & -0.56 & 0.58 & $-0.00-0.00$ \\
Red bat & & & & & \\
Combo & & & & & \\
Intercept & -1.64 & 1.17 & -1.40 & 0.16 & $-3.94-0.66$ \\
ED & 0.00 & 0.01 & 0.56 & 0.57 & $-0.01-0.01$ \\
FOREST & 0.02 & 0.01 & 1.62 & 0.11 & $-0.01-0.05$ \\
SIZE & -0.01 & 0.09 & -1.02 & 0.31 & $-0.02-0.01$ \\
AG & 0.10 & 0.05 & 2.03 & 0.04 & $0.00-0.19$ \\
Open ${ }^{\text {e }}$ & & & & & \\
Intercept & -0.96 & 0.37 & -2.60 & 0.01 & $-1.68-0.24$ \\
URBAN & 0.15 & 0.12 & 1.31 & 0.19 & $-0.08-0.38$ \\
AG & 0.09 & 0.05 & 1.99 & 0.05 & $0.00-0.18$ \\
BARREN & 0.01 & 0.03 & 0.51 & 0.61 & $-0.04-0.06$ \\
DIST & 0.00 & 0.00 & -0.70 & 0.48 & $-0.00-0.00$
\end{tabular}


Table 2-7. Continued.

\begin{tabular}{lccccc}
\hline Parameter & Estimate & $\mathrm{SE}$ & $\mathrm{Z}$ & $\mathrm{Pr}>|\mathrm{Z}|$ & $95 \% \mathrm{CL}$ \\
\hline $\begin{array}{l}\text { Hoary bat } \\
\text { Landscape }\end{array}$ & & & & & \\
$\quad$ Intercept & -2.30 & 1.14 & -2.03 & 0.04 & $-4.53--0.08$ \\
ED & 0.01 & 0.01 & 1.68 & 0.09 & $0.00-0.00$ \\
FOREST & 0.01 & 0.013 & 1.03 & 0.30 & $-0.01-0.04$ \\
WATER & -0.01 & 0.02 & -0.64 & 0.52 & $-0.06-0.03$ \\
WETLAND & -0.51 & 0.30 & -1.74 & 0.08 & $-1.09-0.07$ \\
\hline
\end{tabular}

${ }^{\mathrm{a}}$ Scaled Pearson $\chi 2=128.92, \mathrm{P}=0.56$

${ }^{\mathrm{b}}$ Scaled Pearson $\chi 2=144.52, \mathrm{P}=0.86$

${ }^{\mathrm{c}}$ Scaled Pearson $\chi 2=130.42, \mathrm{P}=0.55$

${ }^{\mathrm{d}}$ Scaled Pearson $\chi 2=126.80, \mathrm{P}=0.51$

${ }^{\mathrm{e}}$ Scaled Pearson $\chi 2=130.50, \mathrm{P}=0.60$

${ }^{\mathrm{f}}$ Scaled Pearson $\chi 2=132.29, \mathrm{P}=0.64$

${ }^{\mathrm{g}}$ Scaled Pearson $\chi 2=130.82, \mathrm{P}=0.61$ 
Table 2-8. Variables included in best approximating candidate models selected using Akaike Information Criteria (AIC $)^{\text {within }}$ multiple regression analysis predicting bat use at wetlands.

\begin{tabular}{lccccc}
\hline Parameter & Estimate & SE & $Z$ & $\operatorname{Pr}>|Z|$ & $95 \%$ CL \\
\hline Species richness $^{\text {Open model }}{ }^{\mathrm{a}}$ & & & & & \\
Intercept & & & & & \\
URBAN & 0.83 & 0.10 & 8.57 & 0.00 & $0.64-1.02$ \\
AG & 0.03 & 0.03 & 1.00 & 0.32 & $-0.03-0.09$ \\
BARREN & 0.02 & 0.01 & 1.68 & 0.09 & $-0.00-0.04$ \\
DIST & 0.01 & 0.01 & 0.92 & 0.35 & $-0.01-0.02$ \\
Combo model $^{\mathrm{b}}$ & -0.00 & 0.00 & -1.86 & 0.06 & $-0.00-0.00$ \\
Intercept $_{\text {ED }}$ & & & & & \\
FOREST & 0.06 & 0.32 & 0.19 & 0.85 & $0.57-0.69$ \\
SIZE & 0.00 & 0.00 & 2.39 & 0.02 & $0.00-0.01$ \\
AG & 0.01 & 0.00 & 1.51 & 0.13 & $-0.00-0.01$ \\
Foraging $_{\text {Combo model }}{ }^{\mathrm{c}}$ & 0.00 & 0.00 & 0.17 & 0.86 & $-0.00-0.00$ \\
Intercept $_{\text {ED }}$ & 0.02 & 0.01 & 1.62 & 0.10 & $-0.00-0.04$ \\
FOREST & & & & & \\
SIZE & & & & & \\
& 2.22 & 0.86 & 2.58 & 0.01 & $0.54-3.90$ \\
& -0.00 & 0.00 & -0.56 & 0.58 & $-0.01-0.01$ \\
& 0.02 & 0.01 & 1.59 & 0.11 & $-0.00-0.04$ \\
& 0.00 & 0.00 & 0.68 & 0.49 & $-0.00-0.01$
\end{tabular}


Table 2-8. Continued.

\begin{tabular}{cccccc}
\hline Parameter & Estimate & SE & Z & $\operatorname{Pr}>|\mathrm{Z}|$ & \multicolumn{1}{c}{$95 \% \mathrm{CL}$} \\
\hline AG & -0.02 & 0.03 & -0.61 & 0.55 & $-0.09-0.46$ \\
Landscape $^{\mathrm{d}}$ & & & & & \\
Intercept & 2.07 & 0.80 & 2.60 & 0.01 & $-0.51-3.63$ \\
ED & 0.00 & 0.00 & -0.47 & 0.64 & $-0.01-0.01$ \\
FOREST & 0.02 & 0.01 & 1.79 & 0.07 & $-0.00-0.04$ \\
WATER & 0.00 & 0.01 & 0.35 & 0.72 & $-0.01-0.02$ \\
WETLAND & 0.03 & 0.11 & 0.27 & 0.79 & $-0.19-0.25$ \\
Open model & & & & & \\
Intercept & 2.59 & 0.28 & 9.21 & 0.00 & $2.04-3.14$ \\
URBAN & -0.13 & 0.10 & -1.28 & 0.20 & $-0.32-0.07$ \\
AG & -0.03 & 0.03 & -0.87 & 0.38 & $-0.10-0.04$ \\
BARREN & -0.01 & 0.02 & -0.36 & 0.72 & $-0.04-0.03$ \\
DIST & -0.00 & 0.00 & -1.81 & 0.07 & $-0.00-0.00$ \\
Little brown bat & & & & & \\
Combo ${ }^{\text {f }}$ & & & & & \\
Intercept & 3.85 & 1.22 & 3.15 & 0.00 & $1.45-6.24$ \\
ED & -0.01 & 0.01 & -1.74 & 0.08 & $-0.02-0.00$ \\
FOREST & -0.01 & 0.01 & -0.37 & 0.71 & $-0.03-0.02$ \\
SIZE & 0.00 & 0.00 & 0.40 & 0.69 & $-0.01-0.01$ \\
AG & -0.10 & 0.05 & -1.99 & 0.05 & $-0.20-0.00$ \\
Origing & & & & &
\end{tabular}


Table 2-8. Continued.

\begin{tabular}{|c|c|c|c|c|c|}
\hline Parameter & Estimate & SE & Z & $\operatorname{Pr}>|Z|$ & $95 \% \mathrm{CL}$ \\
\hline Intercept & 0.60 & 0.70 & 0.85 & 0.40 & $-0.78-1.97$ \\
\hline ORG & 0.09 & 0.44 & 0.20 & 0.84 & $-0.78-0.96$ \\
\hline WET & 1.24 & 0.70 & 2.61 & 0.08 & $-0.13-2.61$ \\
\hline \multicolumn{6}{|l|}{ Open $^{\mathrm{h}}$} \\
\hline Intercept & 2.40 & 0.39 & 6.05 & 0.00 & $1.62-3.17$ \\
\hline URBAN & -0.24 & 0.14 & -1.75 & 0.08 & $-0.52-0.03$ \\
\hline $\mathrm{AG}$ & -0.09 & 0.05 & -1.84 & 0.07 & $-0.19-0.01$ \\
\hline BARREN & -0.04 & 0.03 & -1.40 & 0.16 & $-0.09-0.02$ \\
\hline DIST & -0.00 & 0.00 & -0.11 & 0.91 & $-0.00-0.00$ \\
\hline \multicolumn{6}{|l|}{ Pipistrelle } \\
\hline \multicolumn{6}{|l|}{ Origin $^{\mathrm{i}}$} \\
\hline Intercept & -0.71 & 0.99 & -0.72 & 0.48 & $-2.66-1.24$ \\
\hline ORG & -0.90 & 0.57 & -1.57 & 0.12 & $-2.03-0.22$ \\
\hline WET & 1.87 & 1.00 & 1.86 & 0.06 & $-0.01-3.84$ \\
\hline \multicolumn{6}{|l|}{ Big brown bat } \\
\hline \multicolumn{6}{|l|}{ Open ${ }^{\mathrm{j}}$} \\
\hline Intercept & 1.47 & 0.39 & 3.81 & 0.00 & $0.72-2.23$ \\
\hline URBAN & 0.06 & 0.13 & 0.46 & 0.65 & $-0.20-0.32$ \\
\hline $\mathrm{AG}$ & -0.00 & 0.05 & -0.00 & 0.10 & $-0.09-0.09$ \\
\hline BARREN & 0.03 & 0.03 & 1.00 & 0.32 & $-0.03-0.08$ \\
\hline DIST & -0.00 & 0.00 & -2.00 & 0.05 & $-0.00-0.00$ \\
\hline
\end{tabular}


Table 2-8. Continued.

\begin{tabular}{lccccc}
\hline Parameter & Estimate & SE & $Z$ & $\operatorname{Pr}>|\mathrm{Z}|$ & $95 \% \mathrm{CL}$ \\
\hline Origin $^{\mathrm{k}}$ & & & & & \\
$\quad$ Intercept & 1.87 & 0.56 & 3.32 & 0.00 & $0.77-2.98$ \\
ORG & 0.14 & 0.38 & 0.37 & 0.71 & $-0.60-0.88$ \\
WET & -0.92 & 0.56 & -1.63 & 0.10 & $-2.01-0.18$ \\
Landscape $^{1}$ & & & & & \\
Intercept & 1.20 & 0.96 & 1.25 & 0.21 & $-0.68-3.07$ \\
ED & 0.00 & 0.00 & -0.08 & 0.93 & $-0.01-0.01$ \\
FOREST & 0.01 & 0.01 & 1.21 & 0.23 & $-0.01-0.04$ \\
WATER & -0.04 & 0.02 & -1.69 & 0.09 & $-0.08-0.01$ \\
WETLAND & -0.07 & 0.14 & -0.50 & 0.62 & $-0.34-0.20$ \\
Combo ${ }^{m}$ & & & & & $-0.76-3.10$ \\
Intercept & 1.17 & 0.99 & 1.19 & 0.23 & $-0.01-0.01$ \\
ED & 0.00 & 0.00 & 0.10 & 0.92 & $-0.01-0.03$ \\
FOREST & 0.01 & 0.01 & 0.85 & 0.39 & $-0.02-0.00$ \\
SIZE & -0.01 & 0.01 & -1.77 & 0.08 & $-0.11-0.05$ \\
AG & -0.03 & 0.04 & -0.72 & 0.47 & $-0.01-0.06$
\end{tabular}


Table 2-8. Continued.

\begin{tabular}{|c|c|c|c|c|c|}
\hline Parameter & Estimate & SE & $\mathrm{Z}$ & $\operatorname{Pr}>|Z|$ & $95 \% \mathrm{CL}$ \\
\hline SIZE & -0.01 & 0.01 & -1.53 & 0.13 & $-0.03-0.00$ \\
\hline$A G$ & 0.10 & 0.04 & 2.70 & 0.01 & $0.03-0.18$ \\
\hline \multicolumn{6}{|l|}{ Hoary bat } \\
\hline \multicolumn{6}{|l|}{ Landscape $^{o}$} \\
\hline Intercept & -0.49 & 1.27 & -0.39 & 0.70 & $-2.99-2.00$ \\
\hline ED & 0.00 & 0.01 & 0.65 & 0.51 & $-0.01-0.02$ \\
\hline FOREST & 0.04 & 0.02 & 2.52 & 0.01 & $0.01-0.07$ \\
\hline WATER & -0.03 & 0.02 & -1.08 & 0.28 & $-0.07-0.02$ \\
\hline WETLAND & -0.17 & 0.20 & -0.84 & 0.40 & $-0.56-0.22$ \\
\hline \multicolumn{6}{|l|}{ Combo $^{p}$} \\
\hline Intercept & -0.69 & 1.28 & -0.54 & 0.59 & $-3.19-1.81$ \\
\hline ED & 0.01 & 0.01 & 0.87 & 0.38 & $-0.01-0.02$ \\
\hline FOREST & 0.03 & 0.01 & 2.27 & 0.02 & $-0.00-0.06$ \\
\hline SIZE & -0.01 & 0.01 & -1.22 & 0.22 & $-0.02-0.01$ \\
\hline $\mathrm{AG}$ & 0.00 & 0.05 & 0.02 & 0.99 & $0.10-0.10$ \\
\hline${ }^{\mathrm{a}}$ Scaled Pearson $\chi 2=125.72, \mathrm{P}=0.84$ & \multicolumn{5}{|c|}{${ }^{\mathrm{i}}$ Scaled Pearson $\chi 2=132.09, \mathrm{P}=0.89$} \\
\hline${ }^{\mathrm{b}}$ Scaled Pearson $\chi^{2}=124.23, \mathrm{P}=0.82$ & \multicolumn{5}{|c|}{${ }^{\mathrm{j}}$ Scaled Pearson $\chi 2=145.45, \mathrm{P}=0.98$} \\
\hline${ }^{\mathrm{c}}$ Scaled Pearson $\chi 2=115.46, \mathrm{P}=0.63$ & \multicolumn{5}{|c|}{${ }^{\mathrm{k}}$ Scaled Pearson $\chi^{2}=112.49, \mathrm{P}=0.50$} \\
\hline${ }^{\mathrm{d}}$ Scaled Pearson $\chi^{2}=114.13, \mathrm{P}=0.60$ & \multicolumn{5}{|c|}{${ }^{1}$ Scaled Pearson $\chi 2=105.06, P=0.36$} \\
\hline${ }^{\mathrm{e}}$ Scaled Pearson $\chi 2=113.83, \mathrm{P}=0.59$ & \multicolumn{5}{|c|}{${ }^{\mathrm{m}}$ Scaled Pearson $\chi 2=97.00, \mathrm{P}=0.17$} \\
\hline${ }^{\mathrm{f}}$ Scaled Pearson $\chi 2=138.40, \mathrm{P}=0.96$ & \multicolumn{5}{|c|}{${ }^{\mathrm{n}}$ Scaled Pearson $\chi^{2}=97.24, \mathrm{P}=0.18$} \\
\hline${ }^{\mathrm{g}}$ Scaled Pearson $\chi 2=142.20, \mathrm{P}=0.97$ & \multicolumn{5}{|c|}{${ }^{\mathrm{o}}$ Scaled Pearson $\chi 2=122.58, \mathrm{P}=0.79$} \\
\hline${ }^{\mathrm{h}}$ Scaled Pearson $\chi 2=131.10, \mathrm{P}=0.91$ & \multicolumn{5}{|c|}{${ }^{\mathrm{p}}$ Scaled Pearson $\chi 2=107.07, \mathrm{P}=0.41$} \\
\hline
\end{tabular}




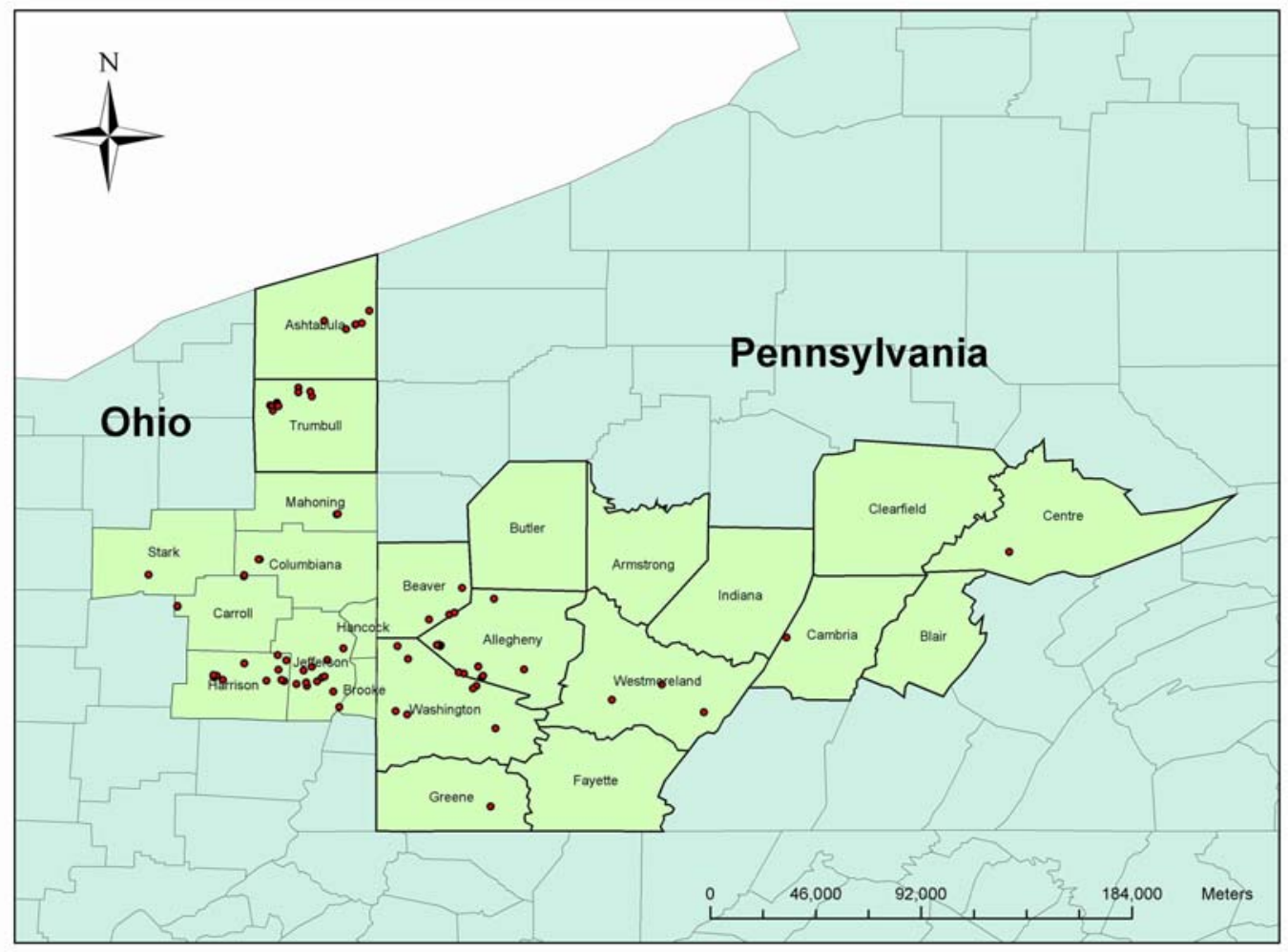

Figure 1. Sampled wetland locations $(n=79)$ in western Pennsylvania and eastern Ohio, June-August, 2004-2005. 
Appendix A. Difference in bat species richness as recorded for each wetland $(n=79)$ by year in western Pennsylvania and eastern Ohio, June-August, 2004-2005.

\begin{tabular}{|c|c|c|c|}
\hline Wetland ID & Richness 2004 & $\begin{array}{c}\text { Richness } 2005 \\
\text { (additional species detected) }\end{array}$ & Total richness \\
\hline 1 & 2 & & 2 \\
\hline 2 & 2 & $4(+2)$ & 4 \\
\hline 3 & 2 & $4(+4)$ & 6 \\
\hline 4 & 3 & $2(+1)$ & 4 \\
\hline 5 & 2 & $1(+1)$ & 3 \\
\hline 6 & 2 & $4(+2)$ & 4 \\
\hline 7 & 2 & . & 2 \\
\hline 8 & 3 & . & 3 \\
\hline 9 & 2 & . & 2 \\
\hline 10 & 2 & . & 2 \\
\hline 11 & 0 & 0 & 0 \\
\hline 12 & 2 & 1 & 2 \\
\hline 13 & 4 & 0 & 4 \\
\hline 14 & 0 & 0 & 0 \\
\hline 15 & 4 & $4(+1)$ & 5 \\
\hline 16 & 0 & 0 & 0 \\
\hline 17 & 2 & $4(+2)$ & 4 \\
\hline 18 & 2 & & 2 \\
\hline 19 & 2 & $2(+2)$ & 4 \\
\hline 20 & 2 & $5(+3)$ & 5 \\
\hline 21 & 1 & $4(+3)$ & 4 \\
\hline 22 & 5 & 0 & 5 \\
\hline 23 & 0 & $1(+1)$ & 1 \\
\hline 24 & 4 & $4(+1)$ & 5 \\
\hline 25 & 3 & $4(+2)$ & 5 \\
\hline 26 & 2 & . & 2 \\
\hline 27 & 4 & 2 & 4 \\
\hline 28 & . & 4 & 4 \\
\hline 29 & . & 1 & 1 \\
\hline 30 & . & 4 & 4 \\
\hline 31 & 2 & $1(+1)$ & 3 \\
\hline 32 & 2 & $2(+1)$ & 3 \\
\hline 33 & 4 & $4(+2)$ & 6 \\
\hline 34 & 0 & $3(+3)$ & 3 \\
\hline 35 & 2 & $3(+1)$ & 3 \\
\hline 36 & 4 & 2 & 4 \\
\hline 37 & 1 & 0 & 1 \\
\hline 38 & 2 & $2(+2)$ & 4 \\
\hline 39 & 0 & 0 & 0 \\
\hline 40 & 5 & $3(+1)$ & 6 \\
\hline
\end{tabular}


Appendix A. Continued.

\begin{tabular}{|c|c|c|c|}
\hline Wetland ID & Richness 2004 & $\begin{array}{c}\text { Richness } 2005 \\
\text { (additional species detected) }\end{array}$ & Total richness \\
\hline 41 & 2 & $3(+2)$ & 4 \\
\hline 42 & 2 & 1 & 2 \\
\hline 43 & . & 1 & 1 \\
\hline 44 & 0 & 1 & 1 \\
\hline 45 & 4 & 2 & 4 \\
\hline 46 & 1 & . & 1 \\
\hline 47 & 1 & $2(+2)$ & 3 \\
\hline 48 & 3 & 0 & 3 \\
\hline 49 & 1 & . & 1 \\
\hline 50 & 2 & 1 & 2 \\
\hline 51 & 0 & 0 & 0 \\
\hline 52 & 0 & 0 & 0 \\
\hline 53 & 4 & 0 & 4 \\
\hline 54 & 4 & $1(+1)$ & 5 \\
\hline 55 & 2 & $2(+1)$ & 3 \\
\hline 56 & 1 & $3(+2)$ & 3 \\
\hline 57 & 3 & $2(+2)$ & 5 \\
\hline 58 & 0 & 0 & 0 \\
\hline 59 & 3 & 0 & 3 \\
\hline 60 & 4 & 1 & 4 \\
\hline 61 & 4 & 1 & 4 \\
\hline 62 & 2 & $1(+1)$ & 3 \\
\hline 63 & 2 & 0 & 2 \\
\hline 64 & 3 & 2 & 3 \\
\hline 65 & 2 & $1(+1)$ & 3 \\
\hline 66 & 4 & $4(+1)$ & 5 \\
\hline 67 & . & 3 & 3 \\
\hline 68 & . & 2 & 2 \\
\hline 69 & . & 2 & 2 \\
\hline 70 & . & 2 & 2 \\
\hline 71 & . & 3 & 3 \\
\hline 72 & . & 3 & 3 \\
\hline 73 & . & 2 & 2 \\
\hline 74 & . & 3 & 3 \\
\hline 75 & . & 0 & 0 \\
\hline 76 & . & 3 & 3 \\
\hline 77 & . & 1 & 1 \\
\hline 78 & . & 2 & 2 \\
\hline 79 & . & 0 & 0 \\
\hline
\end{tabular}

John H. 